\title{
Regional Environmental Governance and Avenues for the Ecosystem Approach to Management in the Baltic Sea Area
}

\author{
Sara Söderström
}

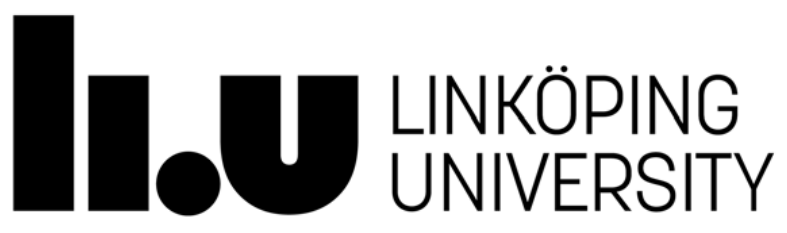

Linköping Studies in Arts and Science No. 705

Faculty of Arts and Sciences

Linköping 2017 
Linköping Studies in Arts and Science • No. 705

At the Faculty of Arts and Sciences at Linköping University, research and doctoral studies are carried out within broad problem areas. Research is organized in interdisciplinary research environments and doctoral studies mainly in graduate schools. Jointly, they publish the series Linköping Studies in arts and Science. This thesis comes from Unit of Environmental Change at the Department of Thematic Studies.

Distributed by:

Department of Thematic Studies - Environmental Change

Linköping University

58183 Linköping

Sweden

Sara Söderström

Regional Environmental Governance and Avenues for the Ecosystem Approach to Management in the Baltic Sea Area

Edition 1:1

ISBN 978-91-7685-606-2

ISSN 0282-9800

Cover image: Photo by Sara Söderström, "Skallknabben”, Mistelhult Archipelago, Sweden

Linköping Studies in Arts and Science • No. 705

(C) Sara Söderström, 2017

Department of Thematic Studies - Environmental Change

2017

Printed by: LiU-Tryck, Linköping 2017 
Regional Environmental Governance and Avenues for the Ecosystem Approach to Management in the Baltic Sea Area

By

Sara Söderström

February 2017

ISBN 978-91-7685-606-2

Linköping Studies in Arts and Science

No. 705

ISSN 0282-9800

\begin{abstract}
This thesis explores the avenues for the ecosystem approach to management in the Baltic Sea Region. This region is one of the most contaminated water bodies in the world, although the first Regional Seas Convention was created here and the region has a long history of cooperation and environmental protection. The current environmental governance arrangements are examined with specific focus on governance structures, cross-sectoral integration and ecological boundaries. The ecosystem approach to management as both a tool and vision of holistic management of natural resources is traced through the evolution of environmental governance, as well as its manifestation in contemporary environmental policies in the region. It is found that the major EU directives, as well as HELCOM polices, promote the ecosystem approach and that its presence has increased in recent years; it is now the major guiding principle in European marine governance. However, the governance structures impede implementation in different ways. The environmental problem areas in the region all require different governance arrangements, thus obstructing a holistic approach. The environmental problems per se also affect each other, necessitating far-reaching sectoral integration and crossborder cooperation, which at present is the major obstacle regarding implementation. The contemporary trends combining solid regionalisation through HELCOM with increased Europeanisation and macro-regionalisation by different EU initiatives offer some promise, but the cross-sectoral impediments must be resolved if the ecosystem approach is to become a practical approach and not just a policy principle.
\end{abstract}

Keywords: Regional Environmental Governance, Ecosystem Approach to Management, Baltic Sea, HELCOM, EU, Shipping 



\section{ACKNOWLEDGMENTS}

The research leading to these results has received funding from the Foundation for Baltic and East European Studies and from the European Community's Seventh Framework Programme (FP/2007-2013) under grant agreement No 217246 made with the joint Baltic Sea research and development programme BONUS.

I first wish to offer my sincere gratitude to my supervisor Professor Björn Hassler whose support and good advice have made this thesis possible, and also to my co-supervisor Associate Professor Johan Hedrén for his warmth and kindness. I also wish to acknowledge Wageningen University and the people at ENP (Environmental Policy Group) for the generous welcome they extended to me as a guest researcher, and naturally all the friends I gained in Wageningen and at other places in the Netherlands. Furthermore, I wish to thank my fellow PhD students and other colleagues for making my days so bright at Södertörn University, they know who they are, and they are awesome! A special thank you also goes to all the experts I have interviewed, without whom this research would not have been possible, so I thank them for adding a human voice to the texts. In addition, anonymous reviewers, proofreaders and others deserve mention as the final product would not been possible without them. Additionally I wish to thank GRID-Arendal for permission to use the map of the Baltic Sea.

Moreover, this work would not have been possible without the solid support of my family and friends. My thanks to Professor Kristine Kern for feedback, support and large amounts of coffee, Dr Elin Olsson for encouragement and for being my solid rock through all these years, Ignè Stalmokaite for keeping me sane in the last, shivering months of my $\mathrm{PhD}$ career, and $\mathrm{Dr}$ Kristina Raab for unconditional support when I needed it most. And finally, my partner Björn and our two children Vega and Grim, who remind me every day that life goes on outside my $\mathrm{PhD}$. Although my mind is occupied with theoretical approaches or wicked problems, I still need to sing a lullaby at the end of the day. Very far from the realms of research.

Live long and prosper.

Huddinge, November 2016

Sara Söderström 


\section{LIST OF PUBLICATIONS}

(I) Söderström, Sara; Kern, Kristine; Boström, Magnus; Gilek, Michael. 2016. 'Environmental Governance' and 'Ecosystem Management': Avenues for Synergies between two Approaches. Interdisciplinary Environmental Review, Vol. 17, No. 1.

(II) Söderström, Sara \& Kern, Kristine. The Ecosystem Approach to Management in Marine Environmental Governance: Institutional Interplay in the Baltic Sea Region. Submitted manuscript.

(III) Söderström, Sara; Hassler, Björn; Kern, Kristine. 2015. Marine governance in the Baltic Sea: Current Trends of Europeanization and Regionalization. In (eds) Governing Europe's Marine Environment. Europeanization of Regional Seas or Regionalization of EU Policies? Ashgate.

(IV) Söderström, Sara. Institutional Interplay in Governing the Baltic Sea Environment: The Role of IMO, EU, HELCOM and Classification Societies as Quasi-governmental Organizations. Submitted manuscript.

\section{List of figures}

Figure 1. The Baltic Sea. Source: GRID-Arendal 2014 (with permission). 


\section{CO-AUTHOR STATEMENT}

(I) Söderström, Sara; Kern, Kristine; Boström, Magnus; Gilek, Michael. 2016. 'Environmental Governance' and 'Ecosystem Management': Avenues for Synergies between two Approaches. Interdisciplinary Environmental Review, Vol. 17, No. 1.

Author responsible for the majority of readings, all database search and statistical presentation. Author responsible for the development of all article sections in cooperation with Prof. K. Kern, Prof. M. Gilek and Prof. M. Boström.

(II) Söderström, Sara \& Kern, Kristine. The Ecosystem Approach to Management in Marine Environmental Governance: Institutional Interplay in the Baltic Sea Region. Submitted manuscript.

Author responsible for the majority of readings, the policy analysis and the empirical part regarding the EAM. Prof. K. Kern is responsible for the theoretical approach. The discussion and conclusion is a cooperation with Prof. K. Kern.

(III) Söderström, Sara; Hassler, Björn; Kern, Kristine. 2015. Marine governance in the Baltic Sea: Current Trends of Europeanization and Regionalization. In (eds) Governing Europe's Marine Environment. Europeanization of Regional Seas or Regionalization of EU Policies? Ashgate.

Author responsible for empirical data collection and development of all article sections in cooperation with Prof. B. Hassler and Prof. K. Kern.

(IV) Söderström, Sara. Institutional Interplay in Governing the Baltic Sea Environment: The Role of IMO, EU, HELCOM and Classification Societies as Quasi-governmental Organizations. Submitted manuscript.

Author responsible for empirical data collection and development of all article sections. 


\section{TABLE OF CONTENT}

1. INTRODUCTION 1

1.1. The research puzzle, aim and research questions 1

1.2. Contribution to literature 2

1.3. Scope: the Baltic Sea 3

1.4. Ecosystem management and the ecosystem approach 3

1.5. Arrangement of thesis 6

2. THEORETICAL OUTLOOK: THE DIFFERENT FACES OF GOVERNANCE 7

$\begin{array}{ll}\text { 2.1. } & \text { The different faces of governance }\end{array}$

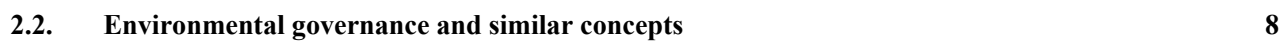

2.3. Regional environmental governance 9

2.3.1. The analytical tool: three main topics of REG 10

2.3.2. Positioning of the papers 11

2.3.3. Main objectives and methods/materials in the papers 12

3. METHODS AND MATERIALS 13

3.1. Process of data collection $\quad 13$

$\begin{array}{lll}\text { 3.1.1. Literature review } & 13\end{array}$

3.1.2. Interview selection $\quad 14$

3.1.3. Conducting the interviews 16

$\begin{array}{lll}\text { 3.2. } & \text { Methods for data analysis } & 17\end{array}$

4. BACKGROUND: GOVERNING THE BALTIC SEA MARINE ENVIRONMENT

4.1. Environmental governance arrangements in the BSR 24

4.1.1. The European Union and the major EU Directives and policies 24

4.1.2. HELCOM and the BSAP 26

4.1.3. International governance and non-state actors $\quad 26$

5. ANALYSIS: THREE TOPICS IN REGIONAL ENVIRONMENTAL GOVERNANCE 29

5.1. Agency: from government to governance 29

5.1.1. Regional actors and interaction between EU and HELCOM 29

5.1.2. State actors and interactions between the EU, HELCOM and Russia 31

5.1.3. Non-state actors and interactions between IMO, the EU and HELCOM 33 
5.2. Substance: EAM and the holistic approach $\quad 34$

$\begin{array}{lll}\text { 5.2.1. } & \text { From hot spot to EAM } & 34\end{array}$

5.2.2. Ambiguities regarding how to define EAM and the role of sector integration 35

5.2.3. Fragmented governance arrangements 36

$\begin{array}{lll}\text { 5.3. Territoriality: the BSR as an eco-region } & \mathbf{3 7}\end{array}$

$\begin{array}{lll}\text { 5.3.1. Regionalisation and Europeanisation of the BSR } & 37\end{array}$

$\begin{array}{lll}\text { 5.3.2. The BSR as an eco-region and macro-region } & 38\end{array}$

6. DISCUSSION: ENVIRONMENTAL GOVERNANCE AND ECOSYSTEM APPROACH TO MANAGEMENT IN THE BALTIC SEA REGION

7. ANNEXES 45

8. BIBLIOGRAPHY 53 


\section{LIST OF ABBREVIATIONS}

\begin{tabular}{|c|c|}
\hline AIS & Automatic Identification System \\
\hline BIMCO & Baltic and International Maritime Council \\
\hline BSAP & Baltic Sea Action Plan \\
\hline BSR & Baltic Sea Region \\
\hline BWMC & $\begin{array}{l}\text { International Convention for the Control and Management of Ships Ballast Water } \\
\text { and Sediments }\end{array}$ \\
\hline CAP & Common Agricultural Policy \\
\hline CBD & Convention on Biological Diversity \\
\hline $\mathrm{CCB}$ & Coalition Clean Baltic \\
\hline CFP & Common Fisheries Policy \\
\hline $\mathrm{COM}$ & Council of Ministers \\
\hline EAFM & Ecosystem Approach to Fisheries Management \\
\hline EAM & Ecosystem Approach to Management \\
\hline ECHA & European Chemicals Agency \\
\hline EMSA & European Maritime Safety Agency \\
\hline EU & European Union \\
\hline EUSBSR & European Union Strategy for the Baltic Sea Region \\
\hline GEG & Global Environmental Governance \\
\hline GEP & Global Environmental Politics \\
\hline HELCOM & Helsinki Commission \\
\hline ICES & International Council for the Exploration of the Sea \\
\hline IEP & International Environmental Politics \\
\hline IGO & Intergovernmental Organisation \\
\hline IMO & International Maritime Organization \\
\hline IMP & Integrated Maritime Policy \\
\hline INSC & International North Sea Conferences \\
\hline INTERTANKO & International Association of Independent Tanker Owners \\
\hline IOPC Funds & International Oil Pollution Compensation Funds \\
\hline
\end{tabular}


IR

ITOPF

IUCN

JCP

MARPOL

MSFD

MSY

ND

NGO

NIP

NSA

NSI

OCIMF

OPRC

OSPAR

PSC

PSSA

RAC

RBD

RBMP

REACH

REG

RO

SOLAS

STECF

TAC

UNEP

WFD

WWF
International Relations

International Tanker Owners Pollution Federation

International Union for Conservation of Nature

Baltic Sea Joint Comprehensive Environmental Action Programme

International Convention for the Prevention of Pollution from Ships

Marine Strategy Framework Directive

Maximum Sustainable Yield

Northern Dimension

Non-Governmental Organisation

National Implementation Programmes

Non-State Actor

National Fisheries Institutes

Oil Companies International Marine Forum

International Convention on Oil Pollution, Preparedness, Response and Cooperation

Oslo-Paris Convention

Port State Control

Particularly Sensitive Sea Area

Regional Advisory Council

River Basin Districts

River Basin Management Plans

Registration, Evaluation, Authorization and Restriction of Chemical Substances

Regional Environmental Governance

Recognised Organisation

International Convention for the Safety of Life at Sea

Scientific, Technical and Economic Committee for Fisheries

Total Allowable Catch

United Nations Environmental Programme

Water Framework Directive

World Wide Fund for Nature 



\section{Introduction}

Environmental problems are major challenges for modern human society. The era of industrialism, globalisation and worldwide political unrest has transformed environmental degradation from local irregularities to complex global collective action dilemmas. Environmental problems are often caused by multiple sources of pollution with uncertain cause-effect correlations, and with different interests colliding where prosperity for some may be the root of distress for others. This complex situation makes governance and management of environmental problems and risks especially cumbersome. The Baltic Sea Region (BSR) is no exception.

The Baltic Sea is a semi-enclosed north-east European sea and is considered one of the most contaminated water bodies in the world, some of the physical characteristics of the area making it especially vulnerable to pollution. Nine countries border this sea, all but one of which, Russia, are part of the European Union. The region is considered a pioneer in terms of environmental cooperation, and the first international conference on the (human) environment took place in this area in the 1970s. The first Regional Seas Convention, the Helsinki Convention, was created here. Environmental collaboration has been prominent in recent decades, where a paradigm shift in environmental policy can be traced through single-issue hot-spot reduction towards holistic thinking through the ecosystem approach as the guiding principle in current regional environmental policies.

\subsection{The research puzzle, aim and research questions}

This thesis critically analyses the contemporary regional environmental governance arrangements in the BSR and the avenues for the ecosystem approach to management (EAM), which is a policy and management tool that has gained momentum in European environmental politics in recent years and as such is promoted as the future of marine environmental governance. EAM is described as an instrument and vision of holistic management considering humans as part of the ecosystem, promoting cross-boundary cooperation and sectoral integration, relying on sound science, stakeholder participation and progressing through adaptive management (Söderström, Kern, Boström, \& Gilek, 2016; Söderström \& Kern, submitted). The notion of regional environmental governance, as a point of departure and analytical tool, is a way of understanding the complex web of the marine environment in the Baltic Sea area, using governance as an analytical framework. As environmental problems take little account of national borders, adopting a governance perspective is an appropriate measure, supported by a growing literature on environmental governance as well as on ecosystem management (Söderström et al., 2016). The Baltic Sea, with its long history of environmental cooperation, stable political structure with a solid regionalisation through HELCOM and Europeanisation through the EU, and currently with EAM as the guiding principle of marine policy, is still one of the most contaminated sea areas worldwide. 
As Tynkkynen et al, 2014 accurate put it: "There is a stark contrast between the formally successful governance system and the actual state of the Baltic Sea.” (Tynkkynen, Schönach, Pihlajamäki, \& Nechiporuk, 2014, p. 105). How could this research puzzle be explained?

Addressing this fundamental query require some delimitations. The focus in this thesis will be on the ecosystem approach to management, as it appears to be the prime tool of contemporary environmental policy in the Baltic Sea Region. The purpose is thus to explore Baltic Sea regional governance with particular emphasis on the ecosystem approach to management, which can be formulated as follows:

The aim of this thesis is to critically analyse the avenues for implementing the ecosystem approach to management in the Baltic Sea Region in terms of policy practices and environmental governance arrangements.

By doing so, the overall governance arrangement in the Baltic Sea marine environment will be explored, through the lens of regional environmental governance. Balsiger and VanDeveer $(2010,2012)$ have created an analytical framework for examining environmental governance in a regional context, which will be followed in this thesis. The analytical framework is described in more detail in the theory section. In order to trace EAM from origin to implementation, the major actors responsible for environmental policy in the region, how they interact and whether or not this interaction contributes to positive or negative outcomes with regard to implementing EAM will be examined. The regional environmental governance arrangements regarding cross-sectoral and cross-issue solutions will also be explored, as well as the spatial scales. The core characteristics of EAM will be matched towards these regional environmental governance arrangements in order to determine the avenues for the implementation of EAM in the region.

The following research questions will be addressed:

(i) Who are the main actors facilitating implementation of EAM in Baltic Sea marine governance?

(ii) To what extent do contemporary environmental governance processes contribute to the implementation of EAM in terms of cross-sectoral and cross-issue solutions?

(iii) In what ways are the governance structures arranged to facilitate EAM in the Baltic Sea as a region in terms of political levels and spatial scales?

\subsection{Contribution to literature}

Environmental governance of the Baltic Sea has been extensively studied (Gilek, Karlsson, Linke, \& Smolarz, 2016b; Joas, Jahn, \& Kern, 2008). However, there are few studies systematically combining the regional environmental governance theme with EAM at a regional level. The major contribution of this thesis is to see how the ecosystem approach to management influences contemporary regional environmental governance, but also how environmental governance arrangements affect the outcome of the approach. The thesis thus 
touches on both the EM literature and literature regarding environmental governance, in doing so integrating concepts from both academic strains in a way that is uncommon, as is shown in paper I. As EAM appears to be promoted as the future basis of environmental policy-making in the BSR marine environment, this thesis fills an information gap in contemporary knowledge of how the EAM is endorsed in the area, at the regional level. By addressing the implementation deficits the thesis also contributes to understanding of the obstacles at hand.

\subsection{Scope: the Baltic Sea}

According to Balsiger and VanDeveer (2010, 2012), compared with global regulations, a region has advantages due to the smaller scale, where knowledge of the regional conditions as well as the main actors is better, together with a common understanding of the environmental problems in the area. A regional focus may also ease the use of ecological borders rather than political ones (Balsiger \& VanDeveer, 2010; Balsiger \& VanDeveer, 2012). There are several aspects that make the Baltic Sea an interesting area of study:

First, the Baltic Sea has some distinctive physical features since it is one of the largest brackish water basins in the world, with specific hydrographical and chemical characteristics (Stankiewicz \& Vlasov, 2009a; Pylähä, 2012). These circumstances make it susceptible to pollution, and the difficulty of navigation through narrow straits in generally icy and shallow water increases the risk of accidents.

Second, the history of the region contributes to specific governance conditions since all nine coastal Baltic States as well as the European Community are part of HELCOM, and all except Russia are part of the EU. The Baltic Sea Region has historically been distinguished by regional cooperation as an ongoing and progressive process, dating back several hundred years in terms of commerce and trade, and a couple of decades with regard to environmental cooperation. However, although the region has many elements to bind the area together, there are still nation states with their own priorities, as well as global institutions such as the IMO and private quasigovernmental organisations which make the overall governance structures an intricate topic of research.

Third, the ecosystem approach to management has recently developed into a major policy tool in environmental governance in the region, as emphasized in the HELCOM Baltic Sea Action Plan (BSAP) and also part of the current EU marine policies. The Baltic Sea Region is also considered one of the leading areas for the implementation of EAM in marine waters (Hegland, Raakjær, \& van Tatenhove, 2015)

\subsection{Ecosystem management and the ecosystem approach}

As discussed in paper I, ecosystem management (EM) is a concept originating in the 1960s. It was recognised as going back to Aldo Leopold's conservation ethics (Garcia, 2003; Szaro, Sexton, \& Malone, 1998), or having sprung from basic ecosystem science (Szaro et al., 1998). Ecosystem management was developed due to the shortages of traditional resource 
management, decreased biodiversity and ecosystem degradation (Szaro et al., 1998). It was emphasised in the seventies and became popular through the UN environmental summits in Stockholm in 1972 and in Rio in 1992; however, a concise definition is yet to be developed (Garcia, 2003). There are numerous terms used when talking about ecosystem management, and with no clear definitions these expressions are often used synonymously. Expressions used are, for example, ecosystem-based management, integrated ecosystem management, total ecosystem management, and the ecosystem approach, which is a term overlapping with ecosystem management (Wang, 2004). As with ecosystem management, the ecosystem approach is not defined and has several variations such as ecosystem-based approach, ecosystem management approach, ecosystem process-oriented approach etc., and there are also a variety of linked expressions such as bioregional approach, bioregional planning, ecoregionbased conservation, watershed management approach, holistic intersectional and interactive approach, 'ecosystem approaches that integrate the conservation and sustainable use of biological diversity as socioeconomic consideration', and the precautionary ecosystem management approach (Wang 2004). The ecosystem approach includes humans as part of ecosystems and is focused on adaptive measures, the precautionary principle and a holistic view of natural management (Naturvårdsverket, 2008; Wang, 2004). However, the ecosystem approach is, at its core, a method for sustainable management of natural resources following ecosystem complexes and boundaries. The essential features originate from the Convention on Biological Diversity (CBD) from 1992, but the approach was not properly developed or defined until a couple of years later at the sixth Conference of the Parties (COP V/6), where twelve principles of the ecosystem approach were established, known as the Malawi principles. ${ }^{1}$ The ecosystem approach is a strategy to attain the goals of CBD: conservation, sustainable resource use and a just distribution of genetic resources, as well as reduced poverty (Hartje, Klaphake, \& Schliep, 2003; Maltby, 2000; Naturvårdsverket, 2008). In the late 1980s, the term 'ecosystem management' started to be commonly used to describe the ecosystem approach to resource management (Szaro et al., 1998), and the terms are still used interchangeably. When ecosystem management is referred to as the ecosystem approach to management, it is often with an addition of some sort, for example the ecosystem approach to fisheries management, or the ecosystem approach to fisheries (Garcia, 2003), or ecosystem-based management for the oceans (McLeod \& Leslie, 2009). The ecosystem approach delineates working methods to attain the goal of the CBD and a common goal and future vision of sustainable use of natural resources, while ecosystem management is often more place-based and anchored in the current human judgement of the management at hand (Maltby, 2000).

\footnotetext{
(1) Management objectives are a matter of societal choice, (2) Management should be decentralized to the lowest appropriate level, (3) Ecosystem managers should consider the effects of their activities on adjacent and other ecosystems, (4) Recognizing potential gains from management there is a need to understand the ecosystem in an economic context, considering e.g. mitigating market distortions, aligning incentives to promote sustainable use, and internalizing costs and benefits, (5) A key feature of the ecosystem approach includes conservation of ecosystem structure and functioning, (6) Ecosystems must be managed within the limits to their functioning, (7) The ecosystem approach should be undertaken at the appropriate scale, (8) Recognizing the varying temporal scales and lag effects which characterize ecosystem processes, objectives for ecosystem management should be set for the long term, (9) Management must recognize that change is inevitable, (10) The ecosystem approach should seek the appropriate balance between conservation and use of biodiversity, (11) The ecosystem approach should consider all forms of relevant information, including scientific and indigenous and local knowledge, innovations and practices, and (12) The ecosystem approach should involve all relevant sectors of society and scientific disciplines (COP V Decision VI6, 2000).
} 
Ecosystem management can accordingly be described as the management of natural resources through the principles of the ecosystem approach. However, there is no clear definition of either concept, and the many notions do not make the picture any clearer. The term ecosystem management has been used since the 1960s, while the ecosystem approach has developed to its current form over the last two decades. In this thesis the term 'ecosystem approach to management' (EAM) is used, meaning management based on the ecosystem approach principles, as defined at COP V/6 and also in practice and in the literature.

The main characteristics of EAM comprise a strong focus on human inclusion in the ecosystem where human use of ecosystem services is managed in sustainable ways, a multi-stakeholder approach in decision-making, a holistic view of conservation, a multi-species approach to protection, and strong reliance on scientific knowledge in management designs. As discussed by Engler (2015), although the concept has been under debate for quite some time, "there is, however, a remarkable consensus on some of the elements of an ecosystem approach, although not necessarily receiving the same emphasis" (Engler, 2015, p. 290-291). The characteristics of EAM are explored in papers I and II, and discussed in more detail below.

(i) Holistic approach with human inclusion: the inclusion of humans as part of the ecosystem is paramount in EAM, which separates ecosystem management from traditional management of natural resources (Endter-Wada, Blahna, Krannich, \& Brunson, 1998; Engler, 2015; Pavlikakis \& Tsihrintzis, 2000; Szaro et al., 1998). It aims to integrate human, biological and natural systems in a holistic approach in a regional, place-based, setting (Pavlikakis \& Tsihrintzis, 2000; Szaro et al., 1998). EAM aims at long-term sustainable development (Naturvårdsverket, 2008; Pavlikakis \& Tsihrintzis, 2000) with a focus on intergenerational equity (Wang, 2004) and a just distribution of genetic resources (Naturvårdsverket, 2008). It is important to protect both the human use of the ecosystem and the natural resources, and to find a balance between socioeconomic development and environmental protection (Endter-Wada et al., 1998; Keough \& Blahna, 2006; Lamont, 2006; Naturvårdsverket, 2008; Wang, 2004). Ecosystem planning thus adopts a holistic view in order to consider several elements of resource use, to ensure environmental protection as well as human exploration of resources, and to ensure that the benefits of one part cannot prevail at the cost of deterioration of another part (Pavlikakis \& Tsihrintzis, 2000; Szaro et al., 1998). Ecosystem management crosses several biological and judicial borders, turning ecosystem management into large management issues, which in turn stress the importance of interagency and/or international cooperation (Wang, 2004).

(ii) Scale-dependent and cross-sectoral integration: EAM is clearly scale-dependent, with the aim of managing a larger, complex ecosystem instead of smaller parts of it. Many biological effects become more evident at larger scale, posing challenges in finding the appropriate scale to manage (Brussard, Reed, \& Tracy, 1998; Engler, 2015; Szaro et al., 1998). An ecosystem, however, is an entity with a wide variety in scale, from very small objects to a system covering the whole planet (Brussard et al., 1998; Szaro et al., 1998). The boundaries between different ecosystems are not always well defined, and the structure and composition of the ecosystem is in constant flux (Szaro et al., 1998). Ecosystems are dynamic with their own characteristics, stressing the importance of a management system that is place-dependent and thus adapted to 
the conditions of the specific area of management, where EM is carried out at the appropriate level in each case: local, national or regional (Wang, 2004). Often the boundaries of the ecosystem to be managed are drawn by geographical occurrences, and thus include the complex systems of organisms as well as the non-living environment (Lamont, 2006).

(iii) Sound science: EAM strives to include all relevant stakeholders and the public in order to consider all parties in a holistic view, resting on the foundation of scientific knowledge (Naturvårdsverket, 2008; Pavlikakis \& Tsihrintzis, 2000; Szaro et al., 1998). Sound science must lay the foundation for the planning and implementation of EAM, and knowledge of ecosystem complexity is a necessity (Engler 2015; Lamont, 2006; Naturvårdsverket, 2008; Wang, 2004). Technical training and international cooperation through exchange of information and knowledge etc. is stressed (Wang, 2004).

(iv) Multi-stakeholder approach / participation: Since ecosystem management is bound by geographical/ecosystem rather than political borders (Endter-Wada et al., 1998; Engler, 2015), stakeholders from diverse jurisdictions are brought together in joint decision-making processes (Lamont, 2006). EAM is collaborative in nature, where face-to-face meetings and consensus seeking is vital, serving to improve transparency and legitimacy (Lamont, 2006). Stakeholders representing different interests are invited to take part in decision-making processes, review scientific material and thus balance the top-down governmental decisions through bottom-up local knowledge (Lamont, 2006; Naturvårdsverket, 2008).

(v) Adaptive management: This participatory practice is also a vital part of adaptive management, which is an interdisciplinary process where experts, policy-makers, scientists and others take part in management (Bunch, McCarthy, \& Waltner-Toews, 2008). Adaptive management explicitly deals with uncertainties and ecosystem dynamics, which means that a flexible management plan is needed in order to adapt to changes in ecosystems (Bunch et al., 2008; Engler 2015). As described by Brussard et al (1998): “Adaptive management allows flexibility and response to uncertainty. It also involves risks and requires that managers accept the potential for irreversible impacts. Nevertheless, it is the only way in which science can be integrated meaningfully into the management process.” (Brussard et al., 1998, p. 18).

\subsection{Arrangement of thesis}

The thesis is arranged in the following way: after this introduction, an in-depth description of the analytical framework is given in chapter 2, relying on concepts related to regional environmental governance, REG. In chapter 3 the methods used for both data collection and data analysis are described. In chapter 4 the Baltic Sea itself is discussed, both in terms of the state of the sea with the main environmental problem areas, but also with regard to the political dimension of contemporary environmental governance. In the following empirical chapter 5, the focus is on three topics in regional environmental governance with regard to the governance arrangements, sectoral integration and cross-boundary cooperation. Finally, chapter 6 discusses the avenues for the ecosystem approach to management in the Baltic Sea Region, with some concluding remarks. 


\section{Theoretical outlook: the different faces of governance}

This chapter explores the concept of governance in terms of scope, characteristics and as a theoretical foundation for this thesis. First a short introduction is given, followed by a summary of the strains of governance approaches, then turning to the notion of regional environmental governance as the heart of the research, presenting an analytical framework.

\subsection{The different faces of governance}

Governance is a concept that has been developed since the 1980 s as an instrument to elucidate the progress of international relations and domestic politics which had moved beyond the traditional boundaries of the nation state and bureaucratic administration (Haward \& Vince, 2008). O'Mahony and Ottaway (2009) write: "Governance describes the processes of rulemaking within boundaries that are non-territorial and non-hierarchical”. (O’Mahony \& Ottaway, 2009, p. 20). Governance is not articulated as a full theory but rather as an analytical perspective (Evans, 2012; Gilek, Karlsson, Linke, \& Smolarz, 2016a) featuring a distinction between governance structures including power relations or regulatory frameworks, and governance processes covering science and policy interfaces, or the development of different strategies (Gilek et al., 2016a). The uses of governance vary enormously, including global governance, corporate governance and European governance or EU governance (O'Mahony \& Ottaway, 2009), adaptive governance (Boyd, 2008), new governance (Gunningham, 2009), effective governance (Haas, 2004), multilevel governance (Bache, 2008; Piattoni, 2010) or related concepts such as governability (Kooiman, 2008) or governmentality (Merlingen, 2011). In the environmental sphere we can find, among other things, ocean governance (Haward \& Vince, 2008), marine governance (Haas, 2000; Joas et al., 2008; Soma, van Tatenhove, \& van Leeuwen, 2015), climate governance (Bäckstrand \& Lövbrand, 2015; Bulkeley, 2010), environmental governance (Chasek, Downie, \& Brown, 2013; Evans, 2012; Joas et al., 2008; Lemos \& Agrawal, 2006), or risk governance (Renn, 2008). New forms of governance have emerged in the wake of globalisation, and the rise of transnational organisations has created new means of authority outside the realm of the nation state; a new world order where 'governance is in the making' (Tamm Hallström \& Boström, 2010). Emerging patterns in practical governance embrace the inclusion of many actors at several levels with multiple rules and steering mechanisms (van Leeuwen, 2010). The notion of 'government' is deep-rooted, while 'governance' is more modern-day, and the concept has developed and diversified rapidly over the last decade (O'Mahony \& Ottaway, 2009). The contemporary discussion of governance includes the often used expression 'from government to governance' which alludes to the distinction between the terms. Governance is not government; it is a broader concept including both state actions and other actors such as business, NGOs and/or communities that are important since they possess significant information or other resources that the nation state lacks (Haward \& Vince, 2008; Lemos \& Agrawal, 2006; Meganck \& Saunier, 2007; Renn, 2008). Nevertheless, the role of traditional governmental authority is not to be ignored in governance (Meganck \& Saunier, 2007) even though the role of authority has shifted in the process of globalization, with new spheres of authority emerging in global governance 
(Rosenau, 2007). It is also important to keep in mind that the concept of a sovereign state is not equivalent to each state possessing the same power (Welch and Kennedy-Pipe 2004).

\subsection{Environmental governance and similar concepts}

The main characteristics of environmental governance include decision-making processes and policy arrangements with a multitude of actors in different arrangements located outside (or inside) the realm of the nation state, all connected to different environmental problems. This is vital with regard to environmental issues since they are cross-boundary and cross-sectoral by nature, as expressed by Evans (2012): “As a practice of governing through cooperation in absence of a centralised state or dictatorial power, governance has obvious use in addressing environmental problems, which are often global in scope and require a vast range of different people to act collectively" (Evans, 2012, p. 6). Environmental governance emphasises collective action and decision-making and can be used as a lens to use when examining the policies of different environmental agendas. The changing nature of the nation state (Lidskog, Soneryd, \& Uggla, 2005) has often been discussed in the light of environmental governance and hence the growth of other institutional arrangements, with new forms of governance emerging, bringing together the state, market and community (Cashore, 2002; Haward \& Vince, 2008; Lemos \& Agrawal, 2006). Major forms of new governance include comanagement (Haward \& Vince, 2008; Lemos \& Agrawal, 2006; Plummer \& Fitzgibbon, 2004) and different kinds of partnerships such as public-private partnerships (Glasbergen \& Groenenberg, 2001; Lemos \& Agrawal, 2006; von Malmborg, 2003), partnership networks (Bäckstrand, 2006), or partnership coalitions (Joyner, 2004). It is also worth noting, as pointed out by Young (2008), that there is a difference between environmental governance and governance for sustainable development, the former covering the protection of the ecosystems of the planet, including human activities, whereas the latter carries a more anthropocentric agenda with the aims of economic growth, social justice and environmental concern, and hence the trade-offs between them (Young, 2008). A concept close to the governance of environmental problems is 'risk governance', and more specifically 'environmental risk governance'. Governing the environment includes a vast array of issues, ranging from smallscale preservation of local species or habitats to intricate and complex conditions with several connecting tiers, such as the climate issue of global warming. Most risks include the characteristics of complexity, uncertainty and ambiguity (Renn, 2008). Environmental risks possess several characteristics that aggravate policy-making and risk assessment, such as risks with low probability and yet high impact, or risks where the uncertainty is very high, creating disagreement amongst experts (Pidgeon, Simmons, \& Henwood, 2006). How people evaluate the risk also differs greatly depending on the probability of gains or detriments, and different kinds of trade-offs (Pidgeon et al., 2006). According to Fiorino (1989), the low-probability high-consequence events are some of the risks where the public assessment differs most from the experts (Fiorino, 1989). Institutional settings of legal and regulatory frameworks must be taken into consideration in risk governance, as well as other contextual features such as political culture and differences in risk perception (Renn, 2008). Of importance to environmental governance is multilevel governance (MLG), which plays a prominent part in contemporary 
EU policies. MLG has developed as a counterview to the dominant outlook of EU studies since the 1960s, where state-centrism is dominant (Bache, 2008). Initially the concept was used to view emerging EU policies and was first employed by Gary Marks in 1992, and since then the notion has been developed to cover a wider view of EU decision-making (Bache, 2008). Having focusing on governance at a broad scale and narrowed it down to focusing on environmental governance, the final stage of regional environmental governance will be further explored below.

\subsection{Regional environmental governance}

The conceptualization of Regional Environmental Governance (REG) forms the theoretical foundation of this thesis. It can be said to be an emergent academic subfield within the more established disciplines of International Relations (IR) and International Environmental Politics (IEP) (Balsiger \& VanDeveer, 2010; Balsiger \& VanDeveer, 2012). The early development of these academic fields in the 1980s was based on the regional dimension as a vital component; however, the status of the region received less attention and was incorporated in the global sphere of IEP. Now, in a world quite different from the one that existed 30 years ago, a call for regional attention is heard from various scholars (Balsiger \& VanDeveer, 2012; Conca, 2012; Debarbieux, 2012). "It is time to bring the regional back in to the study of global environmental politics", write Balsiger and VanDeveer (2012, p.1). It is believed that a world order of international regimes with a growing number of global environmental agreements and connected challenges such as global convention fatigue, ineffective steering and compliance, high transaction costs and yet other difficulties, could benefit from a change in scale, e.g. a shift from global to regional perspectives (Balsiger \& VanDeveer, 2012). Regional environmental governance is a term consisting of three separate entities (the 'region', the 'environment' and 'governance') which form an elusive trinity of interpretations (Balsiger \& VanDeveer, 2012). As thoroughly discussed by Debarbieux (2012), the notion of 'region' is somewhat heterogeneous, the only common ground being to: "...focus on a special kind of spatial entity - supranational or transnational ones.” (Debarbieux, 2012, p. 119). Even though the perception of 'region' is linked to a diverse set of academic understanding and philosophical discussion (Balsiger \& Debarbieux, 2011) the key point is to be aware of this multiple use and thus be clear about the specific use of region in each case (Debarbieux, 2012). This thesis is positioned as having an understanding of the Baltic Sea Region principally as an entity of a specific geographical scope comprising regional institutions such as the EU or HELCOM, covering the Baltic Sea itself. The focus in this thesis is first and foremost on the institutions, while the sea itself is given less attention, although the heterogeneity of the area with respect to political, cultural, economic and historic contexts, as well as environmental features and values, is recognised. In this case the 'region' of the Baltic Sea is what is framed by the EU and the nation states, a superficial region based on the current societal setting which in turn is based on the geographical features of the water body and its catchment area.

Other central characteristics of REG include: (i) The number of regional environmental agreements is on the rise and embrace an expansive vision of sustainable development, (ii) the importance of the multilevel dimension in REG is gaining more attention and enhances the 
understanding of institutional interplay, and (iii) linked to that there is an increased participatory process in international environmental cooperation with the inclusion of non-state actors and subnational governments (Balsiger \& VanDeveer, 2012). In the case of the Baltic Sea Region, the multilevel governance features of EU policy and the macro-regional approach is thus a vital part of the REG in the area. A regional focus has advantages in environmental governance since large-scale environmental operations, such as global treaties, often lead to substantial transaction costs and demand for information. Moreover, important factors such as face-to-face monitoring or culturally embedded authority are hard to manoeuvre at larger scales (Conca, 2012). The rate of success in practice between global and regional environmental arrangements is not clear, and there are success stories and failures at each level (Conca, 2012).

\subsubsection{The analytical tool: three main topics of REG}

In order to analyse REG, three dimensions with topics for agency, substance and territoriality have been developed by Balsiger and VanDeveer as a typology for an analytical space for regional initiatives and a model for empirical research. The analytical framework explicitly aims at facilitating forthcoming studies of REG. In this thesis, the analytical framework will be used to investigate how the three topics of REG (mentioned above) are expressed in the Baltic Sea area. Originally these topics are used as axes in a grid (Balsiger \& VanDeveer, 2010; Balsiger \& VanDeveer, 2012). However, in this study they are used as analytical tools when exploring the environmental governance setting in the region.

The first topic, called agency, concerns the actors in charge of specific regional initiatives, which may involve a wide range of actors from state to non-state, formal and informal, where NGOs or other non-state actors traditionally have had limited influence (Balsiger \& VanDeveer, 2010; Balsiger \& VanDeveer, 2012). In this thesis it covers the institutional dimension regarding the environment in the Baltic Sea Region, where the major actors will be identified and their interactions with regard to environmental policy are explored.

The second topic, substance, refers to the scope of the subject at hand, ranging from singleissue concerns to integrative approaches. Present development appears to be moving in the direction of cross-sectoral integration and widened scope, where the management of regional seas is prominent (Balsiger \& VanDeveer, 2010; Balsiger \& VanDeveer, 2012). The current situation of cross-sectoral and cross-border solutions to environmental problems in the region is investigated in this thesis.

The third topic is that of territoriality. It includes the jurisdictional space of environmental governance arrangements ranging from the core territoriality of the nation states to eco-regions defined by natural or ecological borders (Balsiger \& VanDeveer, 2010; Balsiger \& VanDeveer, 2012). The third topic in this thesis examines the development of eco-regions and also the political advancements of the BSR as a macro-region.

The thesis starts from the assumption that the EAM appears to be an important policy tool in contemporary environmental governance in European politics. The avenues for EAM in the BSR will be analysed through the three topics of agency, substance and territoriality. The 
adapted analytical framework will be used to attain the aim of this study by answering the research questions.

\subsubsection{Positioning of the papers}

The four papers making up this thesis all contribute to the aim in different respects:

The first paper discusses a theoretical background of environmental governance as well as ecosystem management. Several thematic linkages between the two bodies of literature exist, and the paper presents a thorough overview of the concepts that are the foundations of this thesis. The paper examines all three topics of REG since to a major extent it is a literature review: governance structures (state to non-state), sectoral integration (single issue to crosssectoral), and cross-border cooperation (state-centred to eco-regional).

The second paper has a clear focus on the ecosystem approach to management (EAM), and how it is manifested in different policy documents of importance to European marine environmental governance: in HELCOM/BSAP and the EU directives WFD, MSFD and MSPD. It contributes to all three topics of REG.

The third paper gives an insight into the current environmental governance situation in the whole Baltic Sea Region, further investigating the concepts of regionalisation and Europeanisation. The focus is on governance with particular focus on the first topic (state to non-state) and the third topic, nature of territoriality (state-centred to eco-regional).

The fourth paper is a case study of one of the five major environmental problems in the Baltic Sea Region, namely maritime oil transportations. It shows the connection between regional and global governance, demonstrating the difficulty of transboundary environmental hazards. It also shows the intricate nature of environmental governance arrangements, showing that private organisations are acting as quasi-governmental authorities. The paper address all three topics of REG. 


\subsubsection{Main objectives and methods/materials in the papers}

\section{Paper}

(I)

'Environmental Governance' and 'Ecosystem Management': Avenues for Synergies between two Approaches

The Ecosystem Approach to Management in Marine

(II) Environmental Governance: Institutional Interplay in the Baltic Sea Region

Marine governance in the Baltic Sea: Current Trends of

(III) Europeanization and Regionalization

Institutional Interplay in Governing the Baltic Sea Environment: The

Classification Societies as Quasigovernmental Organizations

\section{Main Objectives}

To explore the development and synergies of environmental governance and ecosystem management'

To examine the development of the ecosystem approach to management in European marine policy

To investigate contemporary environmental governance in the Baltic Sea Region in terms of Europeanisation and regionalisation

To analyse the governance structures of shipping and the risk of oil spills and the role of private actors in the governance arrangements

\section{Methods/Materials}

Literature study, database search

Semi-structured interviews, literature study, content analysis

Literature study, content analysis

Semi-structured interviews, literature study 


\section{Methods and materials}

There are several sources of evidence supporting the research in this thesis. As is common in qualitative research, the data is derived from multiple sources (Creswell, 2014) as a way to triangulate the results, i.e. strengthening the findings by collecting evidence from various sources (Bryman, 2002; Creswell, 2014; Yin, 2014). The research relies on information from policy documents (EU Directives, communications, various reports from HELCOM, and other kinds of documents), academic literature and data derived from semi-structured interviews with key stakeholders. The method used for analysing the material is content analysis. A description of the methods used for data collection is first presented below, followed by an account of the methods of analysis of the data material.

\subsection{Process of data collection}

\subsubsection{Literature review}

A literature review was conducted in order to track the origin and development of environmental governance and ecosystem management. The two notions of 'environmental governance' and 'ecosystem management' were compared in the ISI Web of Knowledge/Web of Science (science citation index, SCI, and social science citation index, SSCI). The Web of Science was chosen since it is highly renowned and one of the largest databases for academic literature, and is consequently used by many scholars and scientists. The search was set to the alternative "Topic", covering the whole text body of the paper and therefore including all papers which in some respect mention the term 'ecosystem management' or 'environmental governance'. Consequently the search also takes account of papers that do not mention it at all in the main text but contain a reference that uses the terms in its title and is thus part of the reference list. Since the aim of the database search was to trace the development of a phenomenon over time, it made sense to use one of the oldest and most established terms. Ecosystem management has been used since the mid-1970s, whereas the term ecosystem-based management originates from the early 1990s. The ecosystem approach appears for the first time in the late 1970s but was not commonly adopted until the mid-2000s. Out of a total of 1142 , 854 come from the period 2006-2016. Ecosystem-based management generates 1238 hits, 1150 of these dating from the period 2006-2016. This should be compared with ecosystem management, which generates a total of 3346 hits, of which 2019 come from the period 20062016. The selection of papers and books to read in order to cover the field in a literature review does not include everything there is to read, since all papers mentioning the term 'ecosystem management' or 'environmental governance' amount over 5000. A selection was made here, including papers actively addressing the issues in some respect, some of the most cited papers serving as a starting point pointing the way to identifying other papers of interest, with theoretical papers or those discussing definitions or characters being given priority since that was the scope of the study.

A drawback with an analysis of this kind is that the term ecosystem management has several similar descriptions such as ecosystem-based approach/approaches, ecosystem approach to management, ecosystem approach, ecosystem-based management for natural resources, 
ecosystem process-oriented approach, etc. To make the search results manageable, and also to ensure reliability of the search method, the sole term 'ecosystem management' was used because it is one of the first expressions used comprising a practice that has been developed for quite some time. Using an expression that is narrower or more recently developed would pose a risk of the meta-search becoming more arbitrary and less reliable. Since many of the terms are used interchangeably, a search for 'ecosystem management' could also include a paper discussing the ecosystem approach and so on.

\subsubsection{Interview selection}

Conducting interviews is probably the most commonly used method in qualitative research (Bryman, 2002). In total, twenty-nine interviews were carried out. In order to find interviewees in a certain area, what is known as the snowball effect was used (Bryman, 2002; Esaiasson, Gilljam, Oscarsson, \& Wängnerud, 2003). A number of key people, or 'centrally placed sources', were approached due to their positions in official institutes, organisations, agencies or administrative authorities. Either they agreed to an interview or they recommended another contact (or did not respond at all). Allowing the respondents to recommend further people to contact allows the researcher to utilise the networks of the respondents. This method is common in qualitative research, but the external validity or transferability, for example to what extent the findings can be generalised to a larger sample, remains limited (Bryman, 2002). A drawback with the method is that some people are hard to get hold of, for example it was very difficult to obtain any response from people working for the EU, or in senior positions in an organisation. In certain cases very intensive emailing was needed to get hold of respondents, while in others it was fairly easy to obtain a response. The aim with the interview material was not to make a general model, but rather to investigate a specific situation and thus illustrate and support a case with information. To strengthen internal validity (Bryman, 2002), triangulation with multiple sources of information gained through different methods has been applied, for example when a statement or observation from a respondent is also discussed in the academic literature, thus strengthening the argument.

The majority of the interviews were conducted as part of the RISKGOV project ${ }^{2}$, Environmental Risk Governance in the Baltic Sea Area, a cooperation between Södertörn University, Sweden, Åbo Akademi, Finland, Dialogik, Germany and Gdansk University, Poland. Some interview guidelines with an interview guide were developed to ensure the reliability of the whole material from all four research teams, i.e. that the method of collecting interview material was the same so that the data could be compared in the same way ${ }^{3}$. All the research teams from the four countries were to take part and be able to analyse the data, hence the necessity of good guidance. The interview guidelines provided instructions on how to conduct the interview, with general recommendations and information on preparations, as well as a proper set of questions adapted to each case in the project. However, there was an emphasis

\footnotetext{
${ }^{2}$ www.sh.se/riskgov. The interviews were part of the RISKGOV report "Marine Oil Transportations in the Baltic Sea Area", BONUS deliverable No 6. The whole RISKGOV project used a comparative case study approach regarding five case studies of major environmental hazards in the Baltic Sea: eutrophication, chemical pollution, biodiversity impacts, fisheries and maritime transportations (and the risk of oil spills). These five risks were then compared within the following dimensions: (i) governance structures, (ii) governance processes: risk assessment \& risk management interactions, and (iii) governance processes: stakeholder communication.

${ }^{3}$ General Guidelines for Conducting Interview. Adapted from the Field Guide to Consulting and Organizational Development http://www.managementhelp.org/evaluatn/intrview.htm
} 
on flexibility, and the interview questions were adaptable to the specific case and context of the respondents.

The respondents were chosen because of their commitment to and/or engagement in the development or implementation of one or more of the Baltic Sea Action Plan (BSAP), the EU Water Framework Directive (WFD), the EU Marine Strategy Framework Directive (MSFD) and the EU Marine Spatial Planning Directive (MSPD), with the specific aim of tracing the ecosystem approach to management (paper II) or due to their connection to and position in the vast field of oil transportation (paper IV). Even though the main purpose of the interviews was to gather information and actual facts, the interview selection aimed to cover a vast field of respondents and thus include as many angles as possible. As a consequence of the international nature of shipping many interviewees were members of global organisations. However, the focus was on Europe and the Baltic Sea. Of the twenty-nine interviews three were conducted with representatives from an international NGO (IOPC Funds, ITOPF, BIMCO), two with respondents from the industry (Baltic Exchange, INTERTANKO), two with representatives from green NGOs (Greenpeace, WWF), three from HELCOM (two working groups and Heads of Delegation), four respondents from different areas of the European Union (DG ENVIRONMENT, DG MARE and two from EMSA), one representative from a network organisation in the Baltic Sea area (UBC, Union of the Baltic Cities), two from academia (one researcher from Chalmers University in Sweden and one professor at Gdansk University in Poland), and finally eleven interviewees holding different positions at national governmental agencies (four from the Swedish Transport Agency, one from the Swedish Maritime Administration, three from the Swedish Agency of Marine and Water Management, one from the Government Offices of Sweden, one from the Institute of Meteorology and Water Management in Poland, and two from German governmental agencies). See Annex 1 for full list of interviewees.

A note of concern regarding an interview material as such is that it is a specific view dictated by the respondent's personal experience and opinion (Yin, 2014). The snowball effect is effective due to the fact that it is possible to reach people who might otherwise never be considered, but the sample also becomes subjective in relation to the persons recommended by the interviewees based on their personal experiences. The interview material contains several Swedish respondents, which lessens the external validity. However, the main purpose of the interviews was to gather information and facts rather than personal stories or other narratives in a specific context. Furthermore, the four separate interview sessions with the Swedish Transport Agency could in a sense be counted as one interview since the interview guide for paper IV was extensive (see annex 2) and several of the employees at Swedish governmental bodies recommended their working colleagues for additional interviews because they were unable to answer all the questions. Although working at the same agency, the interviewees came from different departments within the agency, dealing with various aspects for example of shipping (environment, law, surveillance), or maritime issues (the EAM, different descriptors, monitoring) and hence giving different insights although working at the same agency. For example, the Swedish Transport Agency has almost 2000 staff workers in a wide 
range of areas, 375 employees being attached to the division of shipping and aircraft (as of 2016).

\subsubsection{Conducting the interviews}

All interviews carried out were semi-structured; they followed a particular arrangement of questions but were occasionally adapted to fit the background of the respondent (Bryman, 2002). In comparison with the structured interview, the semi-structured interview allows for more flexibility in the interview situation, since it does not strictly follow a questionnaire but rather a set of themes. In comparison with the unstructured interview, the semi-structured interview comprises a framework in which defined topics are covered, i.e. the interview is directed into certain areas. For the topic of this thesis, the semi-structured interview was the best option, allowing for open interviews but still covering predetermined topics. An unstructured interview would not have been appropriate since the aim of the interview was to receive specific information, and to a certain extent also opinions, which require a slight degree of steering. A completely structured interview was not a good option either since the different backgrounds of the informants required a flexible outlook, and if a fixed set of questions was to be applied these would have to be very general, with the risk of missing important topics or views.

The major obstacle while conducting the interviews was to ensure that all topics in the interview guide would be covered, since the respondents came from very dissimilar contexts, but also to keep the time limit set and not be swayed by the enthusiasm of the respondent. With regard to the latter it is possible that the interview is subjective, for example that the respondent is subtly influenced by the researcher's own opinion, and the knowledge and/or prejudice of the subject (Yin, 2014). In order to reduce this risk, it is crucial to stick to the interview guidelines as closely as possible, letting the interviewees talk to an end, not becoming too excited by the discussion and keeping one's own opinions to oneself.

The interviews were conducted face-to-face, by telephone or by video link (Skype). Conducting a face-to-face interview is preferable as one sees the interviewee and can thus, for example, observe body language. All but two of the interviews were recorded (following the preferences of the interviewee), and all were transcribed word-for-word (or summarised on a few occasions). Recording an interview is a good way of capturing the whole interview, which increases transparency and is also important if the interview material is used by several researchers (Bryman, 2002), as in the RISKGOV project. A downside, however, is that the respondent might be influenced by the recorder making him/her uneasy. The only two occasions where the respondents rejected the recorder were face-to-face interviews. All interviewees were asked for permission to record the interview, but although they were aware that the recorder was on, it was not visible through the telephone or video link and may therefore have been of lesser concern. In the cases where the interview was not recorded, the transparency and accuracy was lower, with no possibility of transcription.

Although the face-to-face interviews have several advantages, there are also drawbacks. A disadvantage with face-to-face interviews and recordings is if the venue of the meeting in itself becomes a disturbance and consequently affects the sound of the recording. Another 
disadvantage is the cost, in terms of both money and time, of travelling to meet respondents. In this respect both telephone and video link are much cheaper. These two options thus have the drawback of the quality of the interview being dependent on the quality of the connection, which varies considerably. The video link is a good option for face-to-face interviews since the interviewee and researcher can see each other, but experience from the interview situations in the research for this thesis is that the video calls are of lower quality than a landline. A traditional telephone call is a stable option, not costly and normally with good quality of sound, but with the disadvantage of not seeing the person one is talking to.

Twenty-two of the interviews were conducted by telephone or video link, and seven as face-to face interviews. In all but two cases only one person was present at the interview, and on two occasions more than one person were present in the interview situation (two and three). Of the twenty-nine interviews in total, eighteen were conducted from Sweden (although not necessarily with Swedish informants), three interviews were done in London with respondents based there, and eight interviews were performed from the Netherlands since that was the place of residence at the time, as a result of a three-month researcher exchange trip to Wageningen University.

There are some ethical considerations regarding interviews and respondents. The interviewed experts were all promised anonymity, and permission was given to record the interviews. The material has been used for this research and the RISKGOV project only. Not all interviewees expressed the wish to be anonymous, but in order to present a coherent account of the experts no names are revealed. However, a more detailed description of unit/department and/or position is given in certain cases, by agreement with the respondent.

\subsection{Methods for data analysis}

Three sources of evidence make up the material for analysis in this thesis: academic literature (secondary sources), policy documents such as conventions, directives or reports, and the transcribed texts from the interviews. The methods of analysis comprise a content analysis of the interview material, academic literature and reports, and a policy analysis of four major policy documents.

In order to make sense of the extensive interview material (almost thirty transcribed interviews), content analysis was performed. In essence, this is a method commonly used in the social sciences to find meaning in large quantities of data which are scrutinised in detail through intense readings where the text is divided into clusters and themes (Berg, 1998; Julien, 2008). The main use of the interview material, besides receiving information, was to lend credibility to the study, to seek contradictory or supporting views and to triangulate the data to support the conclusions (Julien, 2008). Following Creswell (2014, p. 196-201), the data analysis of the interview material was performed in the following way: the interviews were transcribed word by word, or in a few cases summarised due to poor sound quality or where the interview was not recorded. All data was scrutinised by a careful read-through to obtain a first impression. An overall summary of all interviews with the major findings was then 
constructed. The transcribed interview texts were coded into themes by carefully reading all interviews and finding common topics which were developed during the reading process, but also themes already determined by the interview guide for the RISKGOV projects. Examples of themes were ecosystem approach, policy implementation, communication strategies, risk assessment or scientific uncertainties. The coding functions as a way of organising extensive material, the themes making it easier to gain an overview of the whole material and make it more manageable. Finally, the interpretive part of the analysis was done, where the 'lessons learned' were identified (Creswell, 2014). This could be when the topics in the themes were fully analysed by identifying the main outcomes of the interviews in the light of the research questions and aims of the papers.

Regarding paper IV, the interview material was broad in scope, covering different issue areas with regard to maritime oil transportation. Here the themes were used to shed light on the different topics in the analytical framework (governance structures, risk assessment, stakeholder communications), and to analyse governance structures, with emphasis on private actors, which was the aim of paper IV. The analysis was thus conducted through a combination of policy documents and specific themes in the interview material which were all directed towards responding to the aim of the study, each containing pieces of information which were assembled to form a larger picture. A similar methodology was adopted in paper II, with the aim of tracing the ecosystem approach to management EAM in terms of origin, development and implementation. However, the principle of using the codes and themes was the same. In this paper content analysis was also conducted in order to trace the EAM references in four of the main directives/policy documents of European marine governance: the HELCOM Baltic Sea Action Plan (BSAP), the EU Water Framework Directive (WFD), the EU Marine Strategy Framework Directive (MSFD) and the EU Maritime Spatial Planning Directive (MSPD). Five key elements of the EAM were identified from thorough literature review, continuing the work already laid out in paper I. The key elements are as follows: (i) holistic approach with human inclusion, (ii) scale dependency, (iii) sound science, (iv) participation, and (v) adaptive management and ecosystem services. These elements were then searched for in all of the above documents to see how EAM had developed conceptually. The analysis was done through a search of these keywords and similar expressions, in each document, but also a careful reading to discover the occurrence of these key elements, although not written explicitly. Other policy documents and reports were also used in this thesis, but only those mentioned above were used in the systematic content analysis. Other documents were used to find more information or trace current policy developments, mainly comprising reports from HELCOM describing a current phenomenon or problem, communications from the EU stating the official policy of a subject, EU Directives, and some other policy documents from Swedish and Polish national agencies. The whole list of documents can be found in Annex 3.

To sum up, the main sources of information used in this study are interview material from twenty-nine semi-structured interviews with key stakeholders, as well as policy documents and academic literature. A literature review was performed to trace the origin and development of environmental governance and ecosystem management in the largest academic database available, the ISI Web of Knowledge. Content analysis was also performed on the major policy 
documents regarding the Baltic Sea marine environment in search of characteristics of EAM, as well as the transcribed interview material in order to pinpoint information connected to the research questions and aims of the papers. 


\section{Background: governing the Baltic Sea marine environment}

This section gives a brief overview of the Baltic Sea marine environment: its characteristics, the major environmental problems in the area and also the governance setting in terms of major institutions affecting the marine environment (as explored in papers II, III, IV).

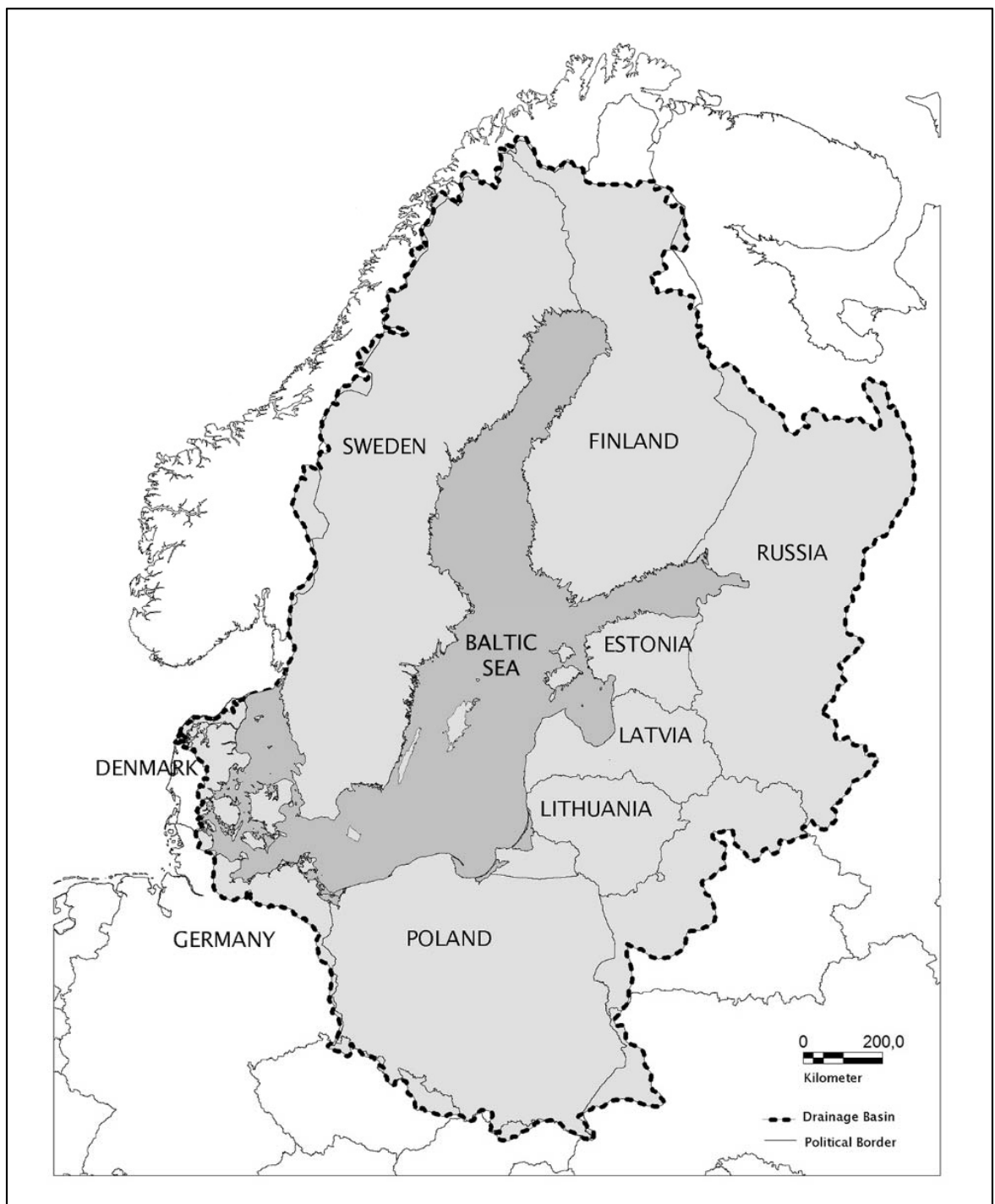

Figure 1. The Baltic Sea. Source: GRID-Arendal 2014 (with permission).

The Baltic Sea is a unique marine area, owing to its young age in geographical terms, but also due to some quite rare characteristics. It is a shallow sea, averaging 60 metres in depth, and the second largest brackish water body on Earth, slightly smaller than the Black Sea (Bernes, 2005). The sole contact with marine water comes from the narrow Danish straits, from where approx. 125 cubic kilometres of ocean water enter the Baltic Sea every year. This should be 
compared to the approximately 500 cubic kilometres of freshwater that reaches the Baltic Sea from the drainage area. Keeping in mind that the whole water body contains around 21000 cubic kilometres of water, it takes about 30 years for the whole water mass to be exchanged by inflow and precipitation (Bernes, 2005). This results in a situation where environmental pollutants that enter the water might remain for a very long time, and it also affects the whole water chemistry. The Baltic Sea has brackish water, on average having one-fifth the salinity of ocean water. High precipitation, large inflow of freshwater and low evaporation keep the salinity low. Nevertheless its salinity is still higher than that of freshwater, resulting in a situation of low biodiversity since few species manage to live under such conditions. Neither marine species nor freshwater species revel in Baltic Sea conditions, which has developed into an ecosystem with few endemic species but where those that manage to survive and thrive under such conditions can be found in quite large numbers (Bernes, 2005). The Baltic Sea ecosystem comprises a limited number of species, although there may be an abundance of individuals within those species, and few species are specialised for specific conditions as is common in older ecosystems. In this respect the system becomes vulnerable, since all species fill specific niches in the ecosystem (known as keystone species) and over-exploitation of species may result in damage not only to local conditions but to the entire food web and consequently whole ecosystems (Bonsdorff, 2006). The main factor controlling the distribution of species in the Baltic Sea is its salinity, high salinity equating to richness in species numbers (Kattegat and Skagerrak) and these numbers dropping as salinity decreases (Lemke, Smolarz, Zgrundo, \& Wolowicz, 2010). Eutrophication, overfishing, bioinvasions (invasive alien species), chemical pollution and maritime transportations are considered the major environmental threats to the Sea.

Eutrophication is considered the greatest threat to the Baltic Sea (Bernes, 2005; Haahti et al., 2010). It is caused by an overload of nutrients in the water, where key parameters are the amounts of phosphorus and nitrogen, chlorophyll a and water transparency, in turn resulting in a change of species composition, excessive algal growth and secondary effects such as oxygen deficiency and declining living conditions, with hypoxic or anoxic bottom areas (dead zones) (Karlsson, Gilek, \& Lundberg, 2016). However, algal blooms and hypoxia are natural phenomenon occurring in the Baltic Sea, although recent decades of human activities have exacerbated the problems (Bernes, 2005). Phytoplankton needs both nitrogen (N) and phosphorus $(\mathrm{P})$ to grow, and there has been a debate as to whether effort should be put into reducing phosphorus, nitrogen or both (Haahti et al., 2010; Johansson, 2006), the current trend pointing towards a joint reduction load (Karlsson et al., 2016). Diffuse sources mostly from agriculture are the main challenges, while the input from point sources has been significantly reduced (Tynkkynen et al., 2014).

Biodiversity is a wide concept, which basically can be said to consist of three levels: (i) genetic, (ii) species or (iii) ecosystem, where marine biodiversity is described as variety, abundance and variability among both organisms and their habitats (Lemke et al., 2010). On a global level bioinvasions, or the introduction of invasive alien species (IAS) are considered to be a major threat to biodiversity, but in the Baltic Sea the problem has attracted little attention (Smolarz, Biskup, \& Zgrundo, 2016). Alien species are introduced either via natural water inflows, or 
through shipping where the species may linger in the ballast water or occur as biofouling on the ships' hulls. IAS may either cause environmental damage or be a threat to economic and public health, where the introduced species can be a threat to native species by competing for resources (nutrients, light, physical space, water, food), contaminating domestic gene pools, introducing pathogens or simply considering native species as prey (Lemke et al., 2010). IAS changes the composition of ecosystems and thus the services provided, however, since the introduction of new species also adds to biodiversity in terms of species richness, and may also provide a new source of goods or services; the problem is twofold and complicated (Smolarz et al., 2016). The rate at which species migrate into the Baltic has increased rapidly over the last 50 years, amplified through synergetic effects with other environmental threats such as eutrophication, overfishing, pollution and climate change (Smolarz et al., 2016). Today there are over a hundred recorded alien species in the Baltic, and there are several examples where invaders have outrivalled native ones, and also where established invaders have been replaced by even tougher ones (Lemke et al., 2010).

Overfishing is another major obstacle to the Baltic Sea environment, but the risk has often been framed in socio-economical terms where the focus is primarily put on human use of a resource (Sellke, Dreyer, \& Renn, 2010). The species of most economic value, and thus fishing pressure, in the Baltic Sea are cod, sprat, herring and salmon (Aps \& Lassen, 2010; Sellke et al., 2010). The size of the fish stocks varies due to natural factors such as salinity, temperature and oxygen (Bernes, 2005). However, in recent decades, fishing pressure on valuable stocks has been massive, pushing many fish stocks into a state of severe decline. The main reason for this development is fishing fleet over-capacity, combined with recreational fishing and also as side effects from tourism and marine pollution (Hassler, Boström, Grönholm, \& Kern, 2011).

The Baltic Sea is often called 'the most contaminated sea in the world', referring to the contamination that began with the industrialisation in the area in the end of the 19th century (HELCOM, 2010). The marine environment of the Baltic Sea is currently subjected to a large number of different chemicals, a threat principally unknown and characterised by great uncertainty. PCBs, DDTs, EDCs (endocrine disruptors) and dioxins are examples of chemical pollution, which in many cases have unclear effects on ecosystems (Karlsson \& Gilek, 2016; Udovyk, Rabilloud, Gilek, \& Karlsson, 2010). As the Baltic Sea is shallow with low water inflow, the hazardous substances accumulate in the environment, where the major sources of pollution are industry, agriculture, traffic and households (HELCOM, 2010). Hazardous substances affect the ecosystem in various ways, including a general decline in health and impaired reproduction in animals (HELCOM, 2010; Karlsson \& Gilek, 2016) as well as health issues in humans where women of childbearing potential are not recommended to eat Baltic Sea fish too often (Udovyk et al., 2010). Some of the species close to extinction has returned in recent years, such as the white-tailed eagle and Baltic Sea seals (Karlsson \& Gilek, 2016)

An oil spill results in major disruption of the local ecosystem. However, the long-term effects of a spill are not well known, and several parameters must be taken into account such as geography, what kind of habitat is affected, water temperature, type of oil etc. (Hassler, Söderström, \& Leposa, 2010). The Baltic Sea is subject to heavy pressure from all kinds of maritime traffic, resulting in various forms of pollution. However, the risk most associated with 
maritime transportations is the risk of oil spills or oily mixtures (Hassler et al., 2010). Shipping is a global activity, and oil is an expensive commodity and a potent contaminant if it is released into the sea. Marine oil pollution can be of two different kinds: accidental or operational (or intentional) oil spills (Hassler, 2016a). Accidental spills occur when oil is released into the water by accident and where the loss of oil is both an economic and environmental setback. Operational oil spills take place when oil is intentionally released into the water, often due to illegal cleaning of tanks at sea in order to save time and money. Although these spills are individually small in most cases, the cumulative total amount of operational oil releases is high (Hassler, 2016a). The global environmental response to large oil spill accidents has largely been reactive; major tanker accidents such as the Torrey Canyon, Exxon Valdez, Erika and Prestige have prompted action, but only after the oils spill have occurred (Uggla, 2007). Although tanker traffic in the Baltic Sea is very extensive, as yet there have been no major oil catastrophes. The entire sea is covered by the Automatic Identification System (AIS), which keeps track of ship traffic. Airborne surveillance keeps track of suspected discharges and satellite images are also provided from the European Maritime Safety Agency (EMSA), and the current trend is for the volume of oil released into the sea to decrease substantially (HELCOM, 2015).

\subsection{Environmental governance arrangements in the BSR}

Having described the major environmental threats to the Baltic Sea marine environment, the focus is now on the major institutions comprising the governance setting for the marine environment in the region, including some global implications, drawing mostly from papers II and III.

\subsubsection{The European Union and the major EU Directives and policies}

The European Union is a regional body and decision-making institution at a European level that profoundly influences the environmental governance of the Baltic Sea. The environmental governance of the EU has evolved from weak interest in the early days of the EEC and progressed towards the strong environmental policy of today (Fairbrass \& Jordan, 2004). This development comprises various groupings of state and non-state actors across different levels and EU environmental policy (Fairbrass \& Jordan, 2004). As expressed by Selin and VanDeveer (2015): “The European Union (EU) is the world's most authoritative international governance system, exercising more influence over its member states than any other international organisation." (Selin \& VanDeveer, 2015, p. 1). There are currently over 500 different EU policy instruments affecting the environment in one way or another (Selin \& VanDeveer, 2015). At present the EU comprises 28 member states and exerts its authority in many issue areas. It is not within the scope of this thesis to examine EU policy in detail. However, some basic understanding of European environmental policy is necessary, and in the following section the major directives and strategies for the European marine governance will be briefly described. 
The Water Framework Directive (WFD) ${ }^{4}$, was adopted in 2000. At that time, it broke new ground as the first Directive to link land use to the management of water resources (Hammer, 2015). It states that: "Water is not a commercial product like any other but, rather, a heritage which must be protected, defended and treated as such.” (WFD, 2000, Recital 1). As discussed in paper III, the goal of WFD is good ecological status and improved water quality in all European waters, and the Directive is characterised by the view that in order to be efficient, water management should follow ecological rather than administrative borders (Söderström, Kern, \& Hassler, 2015). A number of River Basin Districts (RBD) have been identified through the WFD, where the member states are obliged to establish River Basin Management Plans (RBMP) in order to jointly manage transnational marine resources (Söderström et al., 2015)

The Marine Strategy Framework Directive (MSFD) ${ }^{5}$, was adopted in 2008 and has been described as a complement to the WFD connecting inland waters to marine waters (Söderström et al., 2015). The Directive divides European waters into four marine regions, the Baltic Sea being one of them. The main goal is 'good environmental status' measured by eleven quality indicators. The MSFD explicitly relies on the EAM as a foundation for management, as stated in Article 1(3): "Marine strategies shall apply an ecosystem-based approach to the management of human activities, ensuring that the collective pressure of such activities is kept within levels compatible with the achievement of good environmental status and that the capacity of marine ecosystems to respond to human-induced changes is not compromised, while enabling the sustainable use of marine goods and services by present and future generations." (MSFD, 2008, Article 1(3).

The Maritime Spatial Planning Directive (MSPD) ${ }^{6}$, was adopted in 2014. It is part of the new EU integrated maritime policy (IMP) and complements the WFD and MSFD, although it is not an environmental directive per se. However, the use of EAM in all marine spatial planning is stressed, as in Article 3: The IMP identifies maritime spatial planning as a cross-cutting policy tool enabling public authorities and stakeholders to apply a coordinated, integrated and transboundary approach. The application of an ecosystem-based approach will contribute to promoting the sustainable development and growth of the maritime and coastal economies and the sustainable use of marine and coastal resources. (MSPD, 2014, Recital 3).

In 2009, the European Commission published the 'EU Strategy for the Baltic Sea Region' (EUSBSR), complemented by an Action Plan. The goal is enhanced cooperation between the countries, and the strategy explicitly aims at the prospect of reuniting the BSR (Gänzle \& Kern, 2016). Three main objectives are highlighted, namely (i) Save the Sea, (ii) Connect the Region and (iii) Increase Prosperity. Each objective is divided into four sub-objectives and there are also thirteen Policy Areas. The strategy aims at creating a role model for cooperation within the EU, and is the most recent initiative for a healthier Baltic Sea Region (EUSBSR, 2009). The Baltic Sea Region Programme is connected to the EUSBSR and provides financial

\footnotetext{
${ }^{4}$ Directive 2000/60/EC of the European Parliament and of the Council of 23 October 2000 establishing a framework for Community action in the field of water policy

${ }^{5}$ the DIRECTIVE 2008/56/EC OF THE EUROPEAN PARLIAMENT AND OF THE COUNCIL of 17 June 2008 establishing a framework for community action in the field of marine environmental policy

${ }^{6}$ the DIRECTIVE 2014/89/EU OF THE EUROPEAN PARLIAMENT AND OF THE COUNCIL of 23 July 2014 establishing a framework for maritime spatial planning
} 
resources for selected projects. The EUSBSR is the first 'macro-regional cooperation scheme', with the novel aim of being a role model for other regional areas within the EU. The Baltic Sea Region has thus been designated the first EU macro-region, and environmental issues are high on the agenda. The EUSBSR has been designed to consider the region as one area, instead of several units, and thus to bring existing cooperation schemes closer together rather than developing new ones (Bengtsson, 2009; Gänzle \& Kern, 2016). Emphasis is placed on three NOs, meaning NO money, NO institutions and NO new legislation (Stocchiero, 2010).

\subsubsection{HELCOM and the BSAP}

HELCOM could be viewed as an early regionalisation institution in a divided world of east and west by being a facilitator for regional cooperation even during the Cold War, and the organisation has a long history and experience of environmental protection in the region (Hjorth, 1994). It was the first Regional Sea Convention and a pioneer for a sector-integrated view of the protection of the whole marine area (Kern, 2011). Having a regional perspective in mind, awareness of environmental degradation as a transboundary and cross-sectorial phenomenon influences policy arrangements. However, the process towards a more inclusive agenda was developed over several decades with the start of the 'JCP programme' in the 1990s focusing on hot spots, i.e. specific polluted areas in need of enhancement, to the more holistic Baltic Sea Action Plan (BSAP), having an ecosystem approach as its guiding principle. The BSAP represents a new approach in the history of HELCOM by introducing 'ecological objectives' in order to attain improved environmental status. An innovative initiative is the ambition of basing the BSAP on the ecosystem approach and thus, for example, aiming at cross-sectorial solutions (Kern, 2011). The different objectives acknowledge the operating level, i.e. if a measure should be targeting the local, regional, EU or global level. Cooperation with non-HELCOM countries is also encouraged, such as Belarus or Ukraine. Backer et al. (2010) discuss the many activities stressed in the BSAP which have to take place outside the direct realm of HELCOM, and points out that this is a necessity and thus an institutional obstacle to be overcome in order to achieve proper marine management in the region (Backer et al., 2010). The BSAP is funded through the signatories' national budgets and by EU funds (Backer et al., 2010).

\subsubsection{International governance and non-state actors}

Although this thesis has a regional scope, some environmental hazards are not contained within either the geographical or political borders of the Baltic Sea Region. One of the major environmental concerns in the area is the risk of oil spills and other shipping-related hazards, where regional management is not sufficient to address environmental threats with global implications, as explored in detail in paper IV. Nevertheless, there are some regional aspects in the governance arrangements which will be discussed in the next chapter, such as governance structures of regional implications and global aspects. The International Maritime Organisation (IMO) has the major regulatory responsibility for shipping. It is a UN body with 170 member states and is the main platform for the different conventions and regulations in shipping. It is a forum through which suggestions for improvement, new arrangements, legal enhancements and frameworks have to pass. The regulations on oil spills have a hierarchical structure of global reach, due to the global nature of shipping. The total volume of different regulations is 
substantial. Important international conventions are SOLAS (International Convention for the Safety of Life at Sea) and MARPOL (International Convention for the Prevention of Pollution from Ships), MARPOL 73/78 dealing with discharges of oil and oily mixtures and other kinds of waste. OPRC (International Convention on Oil Pollution Preparedness, Response and Cooperation), coordinated by the IMO, is also important.

The shipping regime also comprises several private actors and initiatives, such as classification societies, P\&I Clubs and port state control (PSC). Classification societies are private organisations which are part of the marine safety regime through the ability to inspect and certify vessels according to ship standards, acting as independent bodies with the possibility of succeeding the responsibilities of flag administration (International Association of Classification Societies, 2011). The standards developed by the different classification societies define relevant rules, and vessels in compliance with these rules can apply for a specific Certificate of Classification (International Association of Classification Societies, 2011). The classification process includes inspection of the hull and machinery, and varies depending on class (Basedow \& Wurmnest, 2006). To stay 'in class' ships need to undergo inspections on a regular basis to ensure that they still meet the criteria for certificate holders (Lagoni, 2007). In both IMO and EU legislation, classification societies are known as Recognised Organisations (ROs) (Lagoni, 2007). It is imperative to hold a class certificate in order to insure a vessel, which is of importance, for example, for oil tankers which are carrying a cargo of high value and facing a compensation claim if an accident should happen. Insurance companies thus occupy a key position with regard to maritime safety, and the insurance is often provided by a P\&I Club, which consists of associations handling insurance for ships and shipping activity. The International Group of P\&I Clubs gives a voice to ship owners in the IMO, national authorities, the EU and industry organisations (Hassler et al., 2010). The classification societies have external audits. In European waters they are controlled by EMSA (European Maritime Safety Agency), which is responsible for monitoring and prevention of oil spills. EMSA has a responsibility for strengthening port state control, a control mechanism that has been shown to be of substantial importance in the enforcement of regulatory compliance, since flag state control is often weak.

There are numerous sector organisations of importance within the shipping regime, such as ITOPF (International Tanker Owners Pollution Federation), INTERTANKO (International Association of Independent Tanker Owners) and OCIMF (Oil Companies International Marine Forum), which give technical advice and training or undertake lobbying. There are also several IGOs (intergovernmental organisations) with observer status in the IMO, for example the different IOPC Funds, the International Oil Pollution Compensation Funds, which take legal responsibility and compensate for oil pollution damage from tankers. Green NGOs are less prominent in this area (Hassler et al., 2010).

To sum up, the Baltic Sea is a vulnerable sea area with specific conditions aggravating the environmental hazards. The major threats to a healthy sea are considered to be eutrophication, over-fishing, bioinvasions, chemical pollution and risks connected to shipping, for example oil spills. The environmental governance arrangements in the BSR encompass regional institutions such as the EU and HELCOM, which are member state organisations. There are several 
important policy tools affecting the BSR marine environment, and the characteristics of the environmental problems determine the level of governance. The governance arrangements nevertheless become complex when the environmental problems reach beyond the realms of the EU and HELCOM, creating spaces for several non-state actors and global agencies to influence procedures and henceforth opening for the way to regional regulations that need to be adapted to global arrangements (see chapter 5.1.).

In the following chapter the three topics of REG will be analysed in detail with regard to the ecosystem approach to management Baltic Sea environmental governance. Governance arrangements and their prospects of facilitating EAM in the region will be examined with the focus on the cross-sectoral integration and cross-issue solutions, as well as the BSR as a coherent region in terms of ecological and political boundaries. 


\section{Analysis: three topics in regional environmental governance}

To answer the research questions of this study, an analytical framework constructed by Balsiger and VanDeveer $(2010,2012)$ is used, where the three analytical dimensions of REG provide the key building blocks:

(i) The first dimension concerns agency and the shift from governing to governance. The opening section of this chapter (5.1) describes the overall governance situation in the region, discussing the interactions of the major actors, and thus the formal avenues for EAM in the BSR. This section principally draws on the findings of papers II and IV.

(ii) The second dimension of REG concerns cross-sectoral solutions and whether the governance arrangements consist of single-issue management or cover a broader scope with multi-issue challenges. In the second part (5.2) of this chapter, EAM in Baltic Sea environmental governance is discussed. This section principally draws on papers I and II.

(iii) The third dimension addressed in REG relates to the regional dimension and scales, and zooms in on whether governance structures follow political and administrative borders and what political efforts exist to govern the BSR as a coherent region. In the last part of this chapter (5.3), the Baltic Sea as an eco-region as well as a macroregion is discussed in relation to EAM. This section principally draws on the findings in papers I and III.

\subsection{Agency: from government to governance}

In order to trace EAM components in contemporary governance arrangements, three dimensions of marine environmental governance are discussed: (1) the regional level, consisting of the EU and HELCOM as the major political actors, (ii) the nation states with emphasis on Russia, and (iii) non-state actors at regional and global levels.

As shown in paper II, EAM has influenced the design of the MSFD, MSPD and BSAP, as well as, to a certain extent, the WFD (Söderström and Kern, submitted). Several institutions address the key environmental problems of the region and management arrangements vary accordingly, as showed in the previous chapter. According to Boström et al (2016), four major developments can be traced that have shaped current governance arrangements: (i) the liberation of the Baltic States from the Soviet Union and the democratisation of Poland, (ii) Sweden and Finland becoming members of EU, (iii) the expanded scope of environmental concern during recent decades, and (iv) transnationalisation processes from below including increased interactions from network organisations, green NGOs and other non-state actors. All four developments have contributed to the contemporary governance situation in the region (Boström, Grönholm, \& Hassler, 2016).

\subsubsection{Regional actors and interaction between EU and HELCOM}

The two major regional institutions, the EU and HELCOM, interact in many different ways and dimensions. When comparing HELCOM and EU regulatory mechanisms, HELCOM strategies for environmental improvement can be classified as 'soft law'. Although the Helsinki 
Convention is a legally binding treaty, HELCOM Recommendations are non-binding. The EU applies a different approach than HELCOM, since it enacts binding and enforceable Regulations and Directives. In contrast, the EUSBSR comprises a large number of projects in different issue areas, and primarily exerts agency in the form of steering project selection.

The soft law of HELCOM can in some cases be as effective as hard law. Soft law recommendations can, for example, be negotiated under non-binding conditions and thus later provide foundations for a hard law regime. For example, the non-binding declaration of the International North Sea Conferences (INSC) was incorporated into EU law, and thus strengthened the OSPAR Convention (Skjærseth, Stokke, \& Wettestad, 2006). Similarly, BSAP has been an inspiration for the development of coherent regulations in the EU with regard to marine pollution from shipping, resulting in Directive 2000/59/EC of the European Parliament and of the Council of 27 November 2000 on port reception facilities for shipgenerated waste and cargo residues (Sjöfartsverket 2005). Although the legal position and possible sanctions differ, there are several examples of synergies and fruitful interplay between the EU and HELCOM. One interesting example concerns the connection between the BSAP and the EU MSFD. As discussed in papers II and III, several of the targeted issues are quite similar in these initiatives, and the implementation of the BSAP is boosted by parallel ongoing EU activities, and the two initiatives may be considered as mutually complementary (Backer et al., 2010; Karlsson et al., 2016; Söderström et al., 2015; Söderström and Kern, submitted; van Leeuwen, van Hoof, \& van Tatenhove, 2012; van Tatenhove, Raakjær, van Leeuwen, \& van Hoof, 2014; Wenzel, 2011). It is clearly stated in the MSFD that existing regional structures should be utilised when implementing the directive (MSFD Article 6) and that the MSFD, in turn, should facilitate the fulfilment of BSAP objectives (MSFD Recital 9). HELCOM is responsible for coordinating the MSFD and BSAP. At a Ministerial Meeting in 2010, HELCOM was confirmed as a platform for regional coordination and MSFD implementation in the Baltic Sea (van Leeuwen et al., 2012; Jouanneau \& Raakjær, 2014). As a Senior Analyst at the Swedish Agency for Marine and Water Management put it: "It can be said that the work with BSAP was important for the later MSFD; that it laid the foundation for the Baltic Sea countries to develop their own management plans. So it has been there as a background and base” (interview no 24).

The relations between the MSPD and BSAP are strong, as is the link between the WFD and the MSFD, the two directives being designed to cover all European waters by complementing each other (Söderström et al., 2015). The MSPD can be described as a modern extension of the directives already in place. The WFD, MSFD and MSPD are connected, but with different priority fields, as described by an employee at Swedish Agency for Marine and Water Management, Head of Unit: All three directives are needed. [...] The directives are interoperating (interview no 21).

However, there is differing emphasis in the documents with regard to sustainability, the MSFD and WFD primarily focusing on environmental aspects, while the MSPD to a greater extent targets economic issues (Soma et al., 2015; interview no 29). As shown in paper II, the MSPD is the directive that refers most frequently to EAM. It is clear that the connecting nodes between the WFD and the MSFD are more obvious on paper than in actual implementation. 
For example, the connection between the WFD and MSFD is not so close when it comes to the descriptors and the possibility of linking the data, since different methods that cannot be compared are sometimes used: "the ecological status that is assessed in the WFD is not equal to eutrophication assessment [...] of the principles we have used in the MSFD" (interview no 26). Similar concerns were expressed by another interviewee, who pointed out the difficulties in communicating to politicians that the chemical or ecological status might be considered 'good' under the WFD, but not under the MSFD (interview no 27).

The enthusiasm driving BSAP was initially high, but still not without criticism and disagreements over, for example, national nutrient reduction targets (interviews no 22, 26). Now that almost ten years have passed since the adoption of the BSAP, doubts have been raised as to whether the goals of BSAP and MSFD will be attained in time (Gilek et al., 2016a; Havsoch vattenmyndigheten, 2015b). As discussed in paper II, several of the interviewees argue that BSAP is less important than the MSFD (interviews no 21, 22, 26, 27, 29; Hassler, 2016b). BSAP is mainly viewed as a tool to implement the MSFD, rather than a goal in itself. The link with MSFD affects the form of and ambition for cooperation in HELCOM and redirects efforts to facilitating the MSFD: “[...] the MSFD provides that international organisation structures are used for the coordination of MSFD implementation. This is a challenge as it brings organisations such as HELCOM into close connection with MSFD implementation. Given the different legal implications of international cooperation and EU legislation, Contracting Parties to marine conventions have become very careful in agreeing on regional work as it is feared that it might become legally binding through the MSFD coordination process" (interview no 27).

The decision-making process in HELCOM is described as efficient and open, primarily due to the limited number of member states which all share a common focus (interviews no 7, 26). The fact that the recommendations are non-binding facilitates an open discussion, although HELCOM in many respects has turned into a facilitator of EU directives (interviews no 22, 25, 27, 29). In this sense, the interplay between the EU and HELCOM is synergistic when HELCOM recommendations are raised to the level of legally binding EU regulations. On the other hand, HELCOM adaptation to the EU can sometimes make its own initiatives such as BSAP less visible, and possibly less prioritised among the member states. Another connecting node between the EU and HELCOM is the EUSBSR, which overlaps HELCOM issue areas in several ways and offers regional organisations the possibility of being part of a wider institutional setting. At the same time, the EU can draw from the experiences of these organisations (Gänzle \& Kern, 2016). It is argued that synergies exist between the BSAP and EUSBSR since the latter supports the implementation of BSAP with special emphasis on crosssectoral solutions and thus facilitates EAM (Gänzle \& Kern, 2016). Further details on the EUSBSR are given in section 5.3 of this chapter, when the BSR as a macro-region is discussed.

\subsubsection{State actors and interactions between the EU, HELCOM and Russia}

Member states are of outmost importance regarding the regional seas environment (van Tatenhove, 2016). Both the EU and HELCOM are organisations where states have clear obligations and furthermore affect policies through lobbying and design of decision-making procedures. The MSFD requires member countries to produce Programmes of Measures 
(POMs), and under the BSAP the member states are obliged to produce National Implementation Plans (NIPs). Despite local adaptation being crucial in implementing EAM, neither the EU directives nor BSAP explicitly state how the targets should be met, or how to set up implementation processes (Hassler, 2016b).

As alluded to above, the BSR contains great differences in culture, history and distribution of wealth. The countries furthermore demonstrate varying levels of ambition when it comes to environmental protection (VanDeveer, 2014). The different strategies adopted by the governments lead to promotion or pushing of environmental standards in different directions. In a recent study of the NIPs' eutrophication segment, it was found that administrative and political differences create significant challenges to regional cooperation, with Sweden, Finland, Denmark and Germany applying a broader governance approach, whereas Poland, the Baltic states and Russia adopt more traditional forms of governing, positioning the state as the central unit performing top-down steering (Hassler, 2016b). In scrutinising the most recent NIPs, it becomes clear that EAM does not occupy a central position. The major parts of the NIPs are devoted to EU directives, with the exceptions of Russia and Finland, and the priorities and setup of the NIPs differ considerably (Hassler, 2016b). Nevertheless, EAM is growing in importance in the national policies of the Baltic Sea states. For example, EAM is a requirement in Swedish preparation for marine spatial planning (Havs- och vattenmyndigheten, 2015a), and Polish maritime policy stresses the importance of EAM as well as fulfilling the obligations under BSAP and MSFD (Polish Maritime Policy, 2015). EAM is highlighted and defined in the Polish Water Act (Article 9.1.).

Russian inclusion in the HELCOM cooperation is a matter of substantial importance, as discussed in paper IV As the only non-EU country in the BSR, with massive tanker traffic and a history of pollution, Russian participation is a vital part of the governance system. As a German expert put it: "... back to the policy background of the Baltic Sea region with the fall of the iron curtain in the beginning of the 90s, the coming up of the Baltic Sea republics, the USSR going down, the Russian federation coming back... With the experience of all that, it would be more than a mistake to give up the Russian participation and the Russian cooperation! (interview no 29). An important part of EU environmental policy has therefore been to inspire HELCOM to adapt to EU legislation with the aim of bringing Russian environmental policies closer to those of the EU (interview no 6). "[...] we have to come to account particular interests of Russia. If they say that "well, we are not part of this! We are not bound by the MSFD and we do not want to have that or this particular issue. That just needs to be respected, and it illustrates some challenges there" (interview no 27). Interactions between the EU and Russia have increased over the last four decades, but the level of Russian engagement in different environmental issue areas varies considerably. Although the major conventions on shipping and pollution have been ratified (Gritsenko, 2013; Oldberg, 2014) there is concern that Russian engagement in HELCOM is a way of demonstrating power and offsetting European influence (Tynkkynen, 2014). One example of this may be the failed ambition of making the Baltic Sea a Particularly Sensitive Sea Area (PSSA) under the auspices of the IMO, which could only be achieved with the exclusion of Russian waters (Uggla, 2007). 
The implementation of EAM through the BSAP and the MSFD is coordinated by HELCOM GEAR, a group positioned as facilitator of integrated schemes and regional cooperation between the EU and Russia: "The Group will serve as a regional instrument for the national work of the HELCOM EU Contracting States in implementing the EU Marine Strategy Framework Directive" and "It will also include coordination with activities under the Maritime Doctrine of the Russian Federation” (HELCOM GEAR, 2014, p.1). The GEAR Roadmap of activities takes account of targets that are implemented, agreed or needed (undecided or in need of further resources), in the areas of monitoring, streamlined data management, indicators and GES targets, assessments, and programmes of measures (HELCOM GEAR, 2013).

\subsubsection{Non-state actors and interactions between IMO, the EU and HELCOM}

Although there are well established institutions for environmental governance at the Baltic Sea regional level, certain environmental risks are global in scope and thus require international regulations. Non-state actors (NSA) are often important components of such regulatory arrangements. As discussed in paper IV, shipping activities in the Baltic Sea rely on a complex regulatory system, stretching beyond the region where the IMO functions as a global node. Tendencies towards regulatory overload have been described (Knudsen \& Hassler, 2011), but the overall efficiency of the regime can despite this be described as comparably effective and efficient. The vertical institutional interplay between IMO and EU has created synergies in environmental protection, with the EU pushing for an earlier phase-out of single-hull tankers (van Leeuwen \& Kern, 2013). The EU is a strong actor in negotiations with the IMO, and tensions between the institutions have been described (Söderström, submitted). The vertical institutional interplay between the IMO and HELCOM positions HELCOM as an important regional arena for negotiations. HELCOM member states carefully coordinate positions before IMO negotiations, aiming to achieve opportunities to raise non-binding HELCOM agreements to the level of new or amended IMO conventions. (Söderström, submitted).

As further explored in paper IV, apart from governments and governmental organisations, the shipping regime also comprises private organisations such as classification societies, a rather unusual element of environmental governance structures. Private non-profit organisations are defined in the IMO as Recognized Organisations (ROs), regulated through EU law and controlled by the European Maritime Safety Agency (EMSA). According to Directive 2009/15/EC, vessels navigating European waters must have a certificate issued by a classification society approved by the EU. EMSA is responsible for the enforcement of this mechanism, and in charge of the approval of classification societies. Since ships certified from non-approved classification societies cannot enter European waters, the incentive to have a certificate from a respected classification society remains high (Söderström, submitted). Institutional interplay between the IMO and classification societies is mainly modulated through the possibility of classification societies succeeding the responsibilities of the Flag State. IMO Conventions need to be implemented by Flag States, but this responsibility can be delegated to an RO. From an environmental governance perspective, the interactions between EU and the IMO, where the ROs act as quasi-authorities, adds to the already complex web of institutional arrangement. The implementation of EAM in such a complex governance setting 
is indeed a challenging task, illustrating the difficulties with the scale and scope of an environmental risk.

To sum up, the governance structures include interplay on three levels, between the different directives in the EU where EAM connects the WFD, MSFD and MSPD, between the EU and HELCOM, and between the regional and global levels, where there is interaction between the EU, HELCOM, the IMO and private organisations, as exemplified by the shipping regime (Söderström, submitted, Söderström and Kern, submitted). The most obvious connection is the interplay between the MSFD and BSAP, manifested in practice through HELCOM GEAR. Using existing structures such as regional conventions is a deliberate strategy by the EU to turn HELCOM recommendations into binding EU law. In this process HELCOM has lost part of its independence as a facilitator of MSFD, but it still has a key role in including Russia in the overall governance system (Söderström and Kern, submitted).

\subsection{Substance: EAM and the holistic approach}

The second major topic in regional environmental governance, substance, addresses management of environmental problems stretching from single-issue measures towards broader governance procedures. This chapter will explore the current governance setting in the BSR, comprising the evolution from single hot-spot management towards EAM. Furthermore, the avenues for EAM will be explored in terms of sector integration and cross-issue solutions.

\subsubsection{From hot spot to EAM}

BSR environmental protection is characterised by a shift from a single-issue 'hot spot' approach to adoption of broader scope through EAM. The JCP (the Baltic Sea Joint Comprehensive Environmental Action Programme) was a HELCOM initiative adopted in the 1990s to reduce environmental impacts from anthropogenic sources through what are known as hot spots: environmental problem areas in the Baltic Sea. Over the period 1992-2013 the number of hot spots was reduced from 162 to 53 (HELCOM, 2013). The JCP programme targeted specific point-source pollution problems. Given its rather limited scope, the programme was quite successful with 109 hots spots erased (HELCOM, 2013). As an expert from HELCOM Heads of Delegation put it: "It was really a name and blame list! It was indeed a wish to get rid of these hot spots and it worked quite well. I would say it was one of the most successful HELCOM actions!" (interview no 22).

Although the ambition of JCP was "to restore the ecological balance of the Baltic Sea by reducing pollution loads" (HELCOM, 2013, p. 3) the next major environmental programme, BSAP, adopted a broader scope. BSAP explicitly verbalised the ambition of implementing EAM, which marks a major shift in focus from single-issue targeting to a holistic approach. The marine policy of the EU has progressed in a similar direction. As shown in paper II, EAM components can be traced in the major directives for water and marine environments. Starting with the WFD, it is concluded that full elaboration of EAM is absent, but certain components have been included. In the MSFD, EAM is explicitly defined as a guiding principle, and the recent MSPD could be interpreted as an EU approach to implementing EAM, including 
economic and social sustainability dimensions (Söderström and Kern, submitted). An employee at Swedish Agency for Marine and Water Management portrayed EAM in European policies in the following way: "The EAM, as a principle, has made a huge impact in the different directives. It's in the MSPD, in the CFP and also in the MFSD. If it is filled with some concrete meaning it has its strengths. If the EAM is considered to steer the way the politics are heading it is a strength (interview no 20).

\subsubsection{Ambiguities regarding how to define $E A M$ and the role of sector integration}

Although the evolution of environmental governance in the BSR has moved from single-issue management to more inclusive agendas where the formal guiding principles at the EU, HELCOM and national levels promote the adoption of EAM, some major impediments can be traced in previous research and amongst the interviewees, in particular implementation deficits related to (i) a lack of definition of the EAM, (ii) weak sector integration and (iii) fragmented governance arrangements. Inadequate sector integration and insufficient stakeholder participation reduce the effectiveness of contemporary EAM governance (Gilek \& Karlsson, 2016; Hammer, 2015; Hegland et al., 2015; van Hoof, 2015). Although the MSFD explicitly defines EAM, interpretations differ and uncertainty of implementation prevail. As discussed in the literature (Wang, 2004), a variety of similar terminologies exist, including ecosystem approach, ecosystem-based approach, ecosystem management, ecosystem-based management, ecosystem approach to management and so on. According to the interviewees, awareness of EAM among both the public and practitioners has been growing in recent years. As an employee at the Swedish Agency for Marine and Water Management, Head of Unit, put it: I believe the EAM is on the verge of getting more defined... when it comes to reality. In the beginning it was more of a buzzword. It was mentioned, but no one knew what it was (interview no 21).

Cross-sectoral solutions to solve environmental problems is a fundamental part of EAM, and at the same time a major implementation challenge (Curtin \& Prellezo, 2010; Hegland et al., 2015; van Tatenhove, van Leeuwen \& Soma, 2015). The development seems to be heading towards increased collaboration within sectors, rather than towards bridging of sector borders (Boström et al., 2016). Administrative and sectoral boundaries are very much present, despite cross-sector integration being emphasised in EU, HELCOM and national policy instruments (Söderström and Kern, submitted). For example, the BSAP descriptors for good environmental status are divided into segments, which are characterised by sectoral approaches in most cases (Gilek, Hassler, Engkvist, \& Kern, 2013). Furthermore, the definition of EAM in BSAP emphasises the ecological dimension, whereas social and economic sustainability is less visible, in essence giving environmental ambitions priority over sector integration and stakeholder participation (Curtin \& Prellezo, 2010; Gilek et al., 2013; Hegland et al., 2015). Because HELCOM was created primarily to combat point-source pollution, the wider scope of EAM marine governance has been developed only recently (Hegland et al., 2015). In effect, the institutional structures have not yet been sufficiently realigned to allow for remediation of the obstacles of cross-sectoral integration, although some positive improvements can be discerned, such as initiatives to establish HELCOM communication platforms (Hegland et al., 2015). 


\subsubsection{Fragmented governance arrangements}

The governance of European seas is fragmented, with insufficient cooperation among states. Moreover, sector integration, both domestically and internationally, is somewhat underdeveloped (Mee, 2005). As Hegland et al (2015) put it: “...the present governance setup is characterised by lack of coordination between relevant Directorate Generals within the European Commission, governing bodies of regional Sea Conventions and the member states, within as well as between different sectoral governance arrangements, each with own sets of legal/political instruments, institutional settings and guidelines for stakeholder involvement." (Hegland et al., 2015, p. 15). The fragmented governance structures constitute perhaps the most serious obstacle to effective EAM implementation in the BSR. Different environmental problems are linked to each other in complex ways, for example eutrophication is linked to problems related to overfishing and invasive alien species (Karlsson et al., 2016). There is a need for cross-sectoral solutions not only within but also between problem areas. The differentiation in terms of competences affect these arrangements, where fisheries, for example, are an exclusive EU competence (interview no 29; Sellke, Dreyer, \& Linke, 2016), whereas eutrophication is managed by individual states through action plans derived from the MSFD and the BSAP (Karlsson et al., 2016). Oil spills, in contrast, are mainly governed through global regulations (Hassler, 2016a; Söderström, submitted). Thus, the major marine environmental problems in the BSR all have different governance arrangements (Boström et al., 2016).

The complex governance structure is hampering the adoption of a holistic approach. As eloquently put by a former employee of DG MARE: "I'm afraid that we have a big schism here in the EU, and this all comes back to the Lisbon treaty. That's the main dilemma for the ecosystem approach for marine management; that the competences according to the Lisbon treaty are in very different places" (interview 25). As discussed by almost all interviewed experts, administrative borders between different ministries and departments within the nation states obstruct cooperation and thus severely impede the implementation of EAM. The effects of these sector barriers were described as 'silos' or 'comfort zones', where both communication and cooperation become cumbersome. A professor at the University of Gdańsk, Poland, described the challenge of cross-sectoral solutions as one of the most important obstacles to overcome in order to improve cooperation: "We are used to think in a sectoral way. Maybe it was very useful at the beginning when the administrative structure was born. But now this is not good. [...] Some people are very interested in integrated approaches and holistic approaches, but I think that the regular administration does not have an open mind. Emphasis should be placed on building the administrative capacity for practical cooperation and real coordination" (interview no 28).

To sum up, regional environmental governance of the Baltic Sea has been characterised as a definitive progression in terms of how regulatory instruments are designed and action plans are constructed from targeting single issues and towards more holistic approaches. Sector integration is emphasised as a key element in EAM, together with a more inclusive approach to stakeholders. However, in practice, the ambiguities related to what EAM actually implies 
are a challenge. In addition, fragmented governance structures with dispersed competences and substantial sector cleavages continue to impede effective implementation.

\subsection{Territoriality: the BSR as an eco-region}

The third thematic focus in REG concerns governance strategies ranging from state-centred governing at one end to eco-regional management at the other. Most environmental policies on the Baltic Sea environment espouse an eco-regional approach to sustainable management. The attempts to govern the BSR as an eco-region and transformation to a European macro-region are explored in this section.

\subsubsection{Regionalisation and Europeanisation of the BSR}

As discussed in detail in paper III, the term 'regionalism' often confers ways of bringing geographically and/or administrative units closer together in order to find a common identity. The BSR has a long history of trade and commerce, although the water body itself can also be portrayed as a barrier to integration, separating the relatively wealthy north-west from the south-eastern part. The differences in socio-economic conditions clearly impede effective governance of the Baltic Sea environment (Tynkkynen et al., 2014; Vangas, 2010). The Scandinavian countries are similar with regard to socio-economic structures and have a tradition of cooperation, whereas the former Soviet countries have less developed cooperative structures (Vangas, 2010).

Geographical conditions, as well as history and culture, influence identity. The relative small size of the Baltic countries, combined with a peripheral European location, may contribute to an increased interest in cooperative efforts to reduce risks of marginalisation (Salines, 2010). With regard to environmental issues, regional identity has probably been strengthened by the work of HELCOM, and several authors call for enhanced regionalism in the Baltic Sea in order to address environmental problems more effectively and to facilitate the implementation of EAM (Hegland et al., 2015; van Hoof, 2015). As further discussed in paper III, from being sparsely used before the 1980s, the concept of Europeanisation is increasingly being used by scholars and has become gradually more popular since the late 1990s (Olsen, 2002; Vink \& Graziano, 2007). It is used as a vehicle to examine European policies at national levels, and to interrogate how domestic policy arenas are affected by European policy changes, or, in brief, "the domestic adaptation of European regional integration" (Vink \& Graziano, 2007, p.7), but also how member states shape EU politics and policy (Börzel \& Panke, 2010). The concept of Europeanisation lacks coherent consensus or definition (Bache, 2008; Börzel \& Panke, 2010; van Tatenhove 2016). In this study the Europeanisation adheres to the increased presence of the EU in the BSR, both in terms of member states but also through different regional programmes, and the general effect of EU law through directives. The interpretation of the concept of Europeanisation has evolved into a nuanced understanding of uploading and downloading, where states are influenced by, but also influence, EU policy (Bache, 2008). 


\subsubsection{The BSR as an eco-region and macro-region}

As pointed out in paper II and III, the WFD and the River Basin Management initiatives were aimed at managing water resources through biophysical boundaries, rather than through political and administrative borders (Söderström et al., 2015). Cross-border cooperation with both EU members and non-member states is encouraged in major European policy documents such as the WFD, MSFD, MSPD and BSAP. However, although it is not yet clear how regional cooperation and coordination ought to be structured, there are calls for further regionalisation (Hegland et al., 2015; van Hoof, 2015).

The awareness of differing scales, from local to global, must be taken into consideration when implementing EAM, while carefully assessing ecosystem boundaries (van Hoof, 2015). Determining these ecological boundaries is troublesome, as described by Prellezo, 2010: "Boundaries can be ecological, managerial or geopolitical, so it is very important to set the management regime at corresponding levels. Ecosystems that exist at transnational scales require international cooperation to be effectively managed, while the others must be given an appropriate management level" (Curtin \& Prellezo, 2010, p. 823). The relations between ecological scales and administrative levels is discussed in paper I. Relating to the argument of the previous section with implementation deficits resulting from poor sector integration and fragmented governance arrangements, the scale of the environmental problem also affect EAM implementation. Some environmental problems are best governed at the local level, others demand a regional viewpoint and some, for example shipping (paper IV), mainly fall under international jurisdiction, where the combination of a fragmented institutional setting and several administrative levels hampers the implementation of EAM.

The EU initiative to make the Baltic Sea the first European macro-region through the EUSBSR process can be viewed as an effort to build a bridge between the Europeanisation and European regionalisation, as elaborated in paper III. The way the EUSBSR was created suggests that traditional top-down steering has, at least to some extent, evolved into a regional bottom-up approach with increased stakeholder participation (Gänzle \& Kern, 2015; Rostoks, 2010). However, the different economic capacities and interests of the Baltic Sea countries can make bottom-up processes complicated. It has been observed that the Nordic countries and Germany put environmental issues high on the priority list, while the Baltic States and Poland have emphasised economic cohesion and competitiveness somewhat more (Rostoks, 2010; Salines, 2010; VanDeveer, 2014). The emergence of EUSBSR is considered to be a new governance level operating in the space between the EU and national governance systems (Schymik \& Krumrey, 2009). The EUSBSR is aimed at being a coherent body, gathering existing cooperative schemes and institutions under a unifying umbrella without creating any new institutions. The aim is to increase effectiveness and efficiency within existing institutions and structures (Rostoks, 2010), while avoiding further bureaucratisation (Reinholde, 2010). A core thought is that the macro-regional policy should be flexible and able to adapt to changing circumstances (Bengtsson, 2009).

There are many challenges ahead, for example how to smoothly include third countries in regionalisation processes, but the expressed aim to improve coordination, to adopt regional perspectives and to increase cross-sectoral cooperation is promising. As discussed in section 
5.1.2., the inclusion of Russia in BSR environmental governance is of substantial importance. Because the EUSBSR is an EU project that leaves little scope for non-EU members to take part in the decision-making processes, other fora such as the Northern Dimension (ND) can be used for broader cooperation (Gänzle \& Kern, 2015; Rostoks, 2010). Although the EUSBSR is a European project, it includes several other spheres and third-party actors. It appears that nonmember states have accepted cooperation within the broadened boundaries of EUSBSR, as a mechanism to facilitate cooperation with Russia (Gänzle \& Kern, 2015; Laizāne-Jurkāne, 2010).

To sum up, most environmental policies in the BSR promote the adoption of ecosystem boundaries within the larger framework of EAM, through the BSAP and various EU directives. However, the EAM achievements have so far been more clearly visible in policy documents and action plans than in concrete management. The contemporary environmental governance of the Baltic Sea is characterised by regional institutions and regimes being complemented with the pressures of Europeanisation. The major obstacles to eco- and macro-regional development are third-party interventions, stakeholder participation and unequal distribution of resources, together with diverging agendas among member countries. 


\section{Discussion: environmental governance and ecosystem approach to management in the Baltic Sea region}

Contemporary environmental governance in the BSR encompasses important elements of Europeanisation, comprising key regulatory instruments such as the WFD, MSFD and the MSPD as well as the EUSBSR process. The regionalisation of the area has been evolving for a long time and today, a dense web of regional organisations, networks and cooperative schemes is in place, where HELCOM has been the major regional IGO for the more than 40 years. After the EU enlargement in 2004, the Baltic Sea can be considered a 'European Sea', despite Russia not being a member of the EU.

Ecosystem management, or the ecosystem approach to management, has developed into a comprehensive strategy in European environmental marine governance. Scholarly attention to ecosystem management began over 50 years ago but has since progressed rapidly, while interest in environmental governance was sparked in the 1990s. The concepts have co-evolved in natural and social science to cover two extensive scientific literature bodies with similar themes and concepts, but with only rare interaction (Söderström et al., 2016). Ecosystem management has typically been used as a place-based management plan in a contained area, with the ambition of multi-stakeholder inclusion, cross-border cooperation and adherence to natural borders of the ecosystem, while the academic discussion of environmental governance has traditionally started from a global perspective (Söderström et al., 2016). However, since there are apparent connecting nodes for these two approaches, the viewpoint should rather be to consider ecosystem management, or the ecosystem approach to management, as a vital ingredient in the broader concept of environmental governance.

The avenues for the ecosystem approach to management through environmental governance in the BSR are discernible, but riddled with uncertainties. The Europeanisation processes undertaken through different EU directives and strategies and regionalisation through HELCOM initiatives both adopt EAM as a centrepiece in the vision of sustainable marine governance of the Baltic Sea. Holistic perspectives, sectoral integration and eco-centred modes of implementation are emphasised. However, the implementation phase is the greatest challenge in progress towards effective and efficient environmental governance in the region based on EAM principles. The uncertainty regarding both definition and implementation of the EAM hampers practical application of its principles. Although EAM lacks a broadly accepted definition, this does not necessarily mean that it lacks meaning. Perhaps EAM as a malleable concept will benefit from discussions on what it ought to comprise. For example, contextual differences may have to be allowed to influence which parts of EAM should be emphasised in different contexts. Moreover, the practical implementation of EAM principles probably has to have substantial adaptive capacity to be able to change over time and to adapt to national and local conditions, allowing for EAM as part of a learning process.

The regional environmental governance setting in the BSR could be viewed as follows, with regard to the three topics of REG:

Agency: Who are the main actors facilitating implementation of EAM in Baltic Sea marine governance? The overall governance arrangements in the BSR consist of Europeanisation and 
regionalisation through the EU and HELCOM, and has global implications through non-state actors intersecting with regional agencies. Adoption of EAM is emphasised in several of the main documents and policies regarding regional environmental protection, both from the EU and HELCOM, where the nation states is responsible for the implementation plans. The governance situation is thus a combination of a strong, bottom-up regionalisation already in place, combined with evolving Europeanisation. There are important synergies between HELCOM and the EU where HELCOM is appointed the regional agency responsible for MSFD implementation, but also due to the uploading of HELCOM initiatives to EU level. However, HELCOM and BSAP have sometimes become somewhat crowded out by the increasing presence of the EU and because EU obligations supersede the soft law requirements of HELCOM. The EUSBSR can be considered a new and complementary mode of governance merging Europeanisation with a regional approach through the creation of a macro-region. The EUSBSR is a shift from the traditional top-down Europeanisation process to including a more bottom-up regionalisation approach through the inclusion of actors and stakeholders.

Substance: To what extent do contemporary environmental governance processes contribute to the implementation of EAM in terms of cross-sectoral and cross-issue solutions? The EAM is a rather recent paradigm in contemporary environmental governance. Moving from an almost exclusive focus on point-source pollution toward the ecosystem approach has gained momentum since the CBD and Malawi principles, and EAM now holds a solid position in marine policy and the environmental governance of the Baltic Sea. Europeanisation, regionalisation and macro-regionalisation have been key components in this development. However, substantial implementation deficits have led to discrepancies between official policies and observed outcomes in terms of ecological improvements. Arguably, contemporary governance structures still rely on states' interests and capabilities, where the different competences of the EU add to the difficulties of implementing stated policies in effective ways. The ambition of governing the marine environment in a holistic way is clearly stated, but the very nature of the environmental problem requires different governance settings which, in some cases, extend beyond the region and thus require a broadened spatial scope and more complex governance designs. In some cases, these governance structures become very complex with intricate links between regional and global organisations as well as private actors, which all contribute to the larger governance structure. Increased stakeholder participation is a key topic in current scholarly and political discussions, but there is no consensus on how this will be implemented and become part of a robust and sustainable governance structure.

Territoriality: In what ways are the governance structures arranged to facilitate EAM in the Baltic Sea as a region in terms of political levels and spatial scales? Regarding broader cooperative initiatives in the BSR, the EU and HELCOM have several overlapping issue areas and connecting points, where EUSBSR functions also as a facilitator for cooperation with nonEU member states, especially Russia. The governance arrangements are currently not adapted to how different environmental problems are most effectively approached, and existing governance structures have not yet become fully matured to cope with all the implementation deficits. For example, the role of the EUSBSR is not settled, and although HELCOM seems to have aligned more with the EU at the expense of its own independence, the current broadening 
of perspective is. Of particular importance are the many initiatives to bring Russia into closer cooperation with the EU in general and HELCOM and EUSBSR processes in particular. The holistic approaches and emphasis on cross sectoral integration in the BSR is a good example of a region with an advanced environmental policy mix paired with often weak implementation.

The need for a more consistent governance of the Baltic Sea environment is stressed by many observers, and the fragmentation of EU competences and sectors generates obstacles to improvements. The EU ambition to create a coherent region out of a regional sea, comprising states with substantial differences in GDP, history and administrative traditions has proven to be difficult. Voices have also been raised concerning potential threats to the legitimacy of the development of regionalisation, the view that proactive and resourceful countries gain too much influence, even though the official channels are open to everyone. This may jeopardise the long-term robustness and sustainability of the regionalisation process. Arguably, it would be valuable to somehow find reasonably well-balanced compromises among countries with varying interests. The future governance of the region will most likely depend on how bottomup regionalisation processes fit into EU top-down strategies, and on the extent to which Europeanisation and regionalisation processes can be merged into an inclusive governance approach, with deep stakeholder involvement and bridged sectoral cleavages.

The BSR as an eco-region and macro-region has some novel characteristics. EAM clearly states that ecosystems should be the fundamental building blocks for effective governance design. But determining ecosystem boundaries is difficult, especially when economic and social systems should be included as well in the delimitation of regional spaces. Europeanisation (EU Directives and EUSBSR) offers some promising prospects for cross-border cooperation and strengthening of regional identity, which in turn may facilitate EAM through intensified environmental collaboration between states within and beyond the region. As environmental problems rarely respect the borders of the nation state, cross-border cooperation at different levels is essential for the future of the Baltic Sea environment. 


\section{Annexes}

\section{ANNEX 1: The interviewees}

\begin{tabular}{|c|c|c|c|}
\hline Int. No & Type of Org. & $\underline{\text { Name }}$ & $\underline{\text { Unit/dept. Position }}$ \\
\hline 1 & INGO & IOPC Funds & Legal Counsel / Technical Adviser \\
\hline 2 & INGO & ITOPF & Technical Team Manager \\
\hline 3 & Industry & Baltic Exchange & Shipbroker and freight market reporter \\
\hline 4 & Industry & INTERTANKO & Marine manager, assistant regional manager \\
\hline 5 & Green NGO & Greenpeace & Marine officer \\
\hline 6 & GOV & HELCOM & Working group \\
\hline 7 & INGO & BIMCO & Senior marine technical officer \\
\hline 8 & EU & DG ENVIRONMENT & Communication Unit $(\mathrm{ENV} / \mathrm{F} / 3)$ \\
\hline 9 & GOV & HELCOM & Working group \\
\hline 10 & Network ORG & $\mathrm{UBC}$ & Botkyrka \\
\hline 11 & Green NGO & WWF & Conservation Officer \\
\hline 12 & Research & Chalmers University, Sweden & Dept. of Shipping and Marine Technology \\
\hline 13 & EU & EMSA & Unit of Marine Environment, Training \& Statistics \\
\hline 14 & EU & EMSA & Project officer \\
\hline 15 & Nat GOV (SWE) & Swedish Transport Agency & Maritime Department, Environmental Unit \\
\hline 16 & Nat GOV (SWE) & Swedish Transport Agency & Swedish Maritime Safety Inspectorate \\
\hline 17 & Nat GOV (SWE) & Swedish Transport Agency & Ship Operational Unit \\
\hline 18 & Nat GOV (SWE) & Swedish Transport Agency & Supervisory Unit \\
\hline 19 & Nat GOV (SWE) & Swedish Maritime Administration & Administrative officer, environment and int. cooperation \\
\hline 20 & NAT GOV (SWE) & Swedish Agency for Marine and Water Mng. & Unit of Maritime Spatial Planning and Maritime Affairs \\
\hline 21 & NAT GOV (SWE) & Swedish Agency for Marine and Water Mng. & Marine Spatial Planning, Head of Unit \\
\hline 22 & GOV & HELCOM & Head of Delegation \\
\hline 23 & NAT GOV (SWE) & Government Offices of Sweden & Ministry of Environment \\
\hline 24 & NAT GOV (SWE) & Swedish Agency for Marine and Water Mng. & Division for Marine and Water Management \\
\hline 25 & $\mathrm{EU}$ & DG MARE & Expert \\
\hline 26 & NAT GOV (PL) & Inst. of Meteorology and Water Management & Researcher \\
\hline 27 & NAT GOV (GER) & Governmental ministry / agency, Germany & Expert \\
\hline 28 & Research & University of Gdańsk, Poland & Professor \\
\hline 29 & NAT GOV (GER) & Governmental ministry / agency, Germany & Marine Director \\
\hline
\end{tabular}




\section{ANNEX 2: Interview guidelines}

Interview guidelines for paper II:

1. Could you describe your work regarding the BSAP/WFD/MSFD/MSPD?

2. The BSAP/WFD/MSFD/MSPD is connected with and refers to several other policy documents, conventions, directives or legislation. In the BSAP/WFD/MSFD/MSPD there is an emphasis on no new legislation and the directive having to serve as a means of attaining the goals of other directives or policy documents. How was this discussed in the initial phase when formulating the policy? / How is this working in practice today?

3. What are the channels used when formulating or working with a directive/policy? How is the work being done in practice?

4. Who are the people/the actors involved in the process? / Implementation?

5. How did you experience the work with the ecosystem approach to management? How was it discussed during the development? / Implementation? Did the notion of the ecosystem approach to management change during the process?

Interview guidelines for RISKGOV project and paper IV:

1. Topic: Framing the risk of oil spills

1.1. When you look at the risk of oil spills; what do you see as the main problem, the main risk so to speak?

1.2. Are you aware of any means to reduce the risk?

1.3. Who are most affected by the risk of oil spills?

2. Topic: Requlatory frameworks

2.1. In general, how do you see existing regulatory system for risk management of oil spills in the Baltic Sea region? Is sufficient or can you see room for improvements?

- How could this be?

2.2. Does your organization cooperate with other organizations for improving risk management of the risk of oil spills in the Baltic Sea? Or if not in the Baltic, elsewhere?

- What do you do in order to facilitate collaboration, coordination and synergies for effective risk governance in the Baltic Sea? Or if not in the Baltic, elsewhere?

- Do you see any obstacles in the current situation?

2.3. Do you see any differences in interests among governmental bodies, regulatory frameworks, policies and other risk management elements?

- If YES: Do you believe your organization can be of help in improving these interactions?

2.4. Can you identify any significant changes over the time in the risk management concerning the risk of oil spills in the Baltic Sea area?

2.5. Did the EU enlargement or USSR break down affect the risk management of oil spills in the region?

- If YES: In what sense? Can you give particular examples?

3. Topic: Risk assessment

3.1. Does your organization perform risk assessments regarding oil spills as such?

- If YES: Who is performing risk assessment in your organization? Or where do you receive risk assessment information from?

- What type of expertise is required in order to do risk assessments? 
- What are the reasons for the risk assessment to be performed? Is this a basic scientific research? Is this a consultancy task? Employer priorities etc?

- How do you communicate with risk managers? How are these communicational links organized? Can you describe the way you communicate?

- Which risk assessment is in place /implemented?

- Which risk assessment activities are requested by existing policy regulations? Are there other regulations to take into consideration?

3.2. Do you see that the assessment or management of oil spills relate to other (environmental) risks in the Baltic Sea region?

3.3. Can you identify the differences in national views? How do you dealt with it?

4. Topic: Ecosystem approach to manaqement (EAM)

4.1. Does your organization in any sense deal with the ecosystem approach to management (EAM)?

- If YES: In what ways?

- Which major benefits do you see with the EAM?

- Which major obstacles do you see with the EAM?

- How do you perceive the role of your organization and EAM over time? Has this role changed when the EAM was implemented? OR: Do you anticipate the role to change when the EAM is implemented?

5. Topic: Communication

5.1. Does your organization network in any way?

5.2.In which ways does your organization deal with communication? // OR risk communication in regard of oil spills? When (in the procedure)? Why? To whom? In what way? What are the structures and procedures in which communication take place? In which forms is the risk of oil spills mainly communicated? Who are the target-groups for information in the case of communication? Do you consider the different aspects of environmental, economic and social objectives?How is the view of different stakeholders engaged into communication activities? Do you see any problems in the existing risk communicating activities? What can be done to improve current risk communication practice?

5.3. Do you include the public/public participation in any way?

5.4. Do you know any institutions at the Baltic Sea level with responsibility for communicating risk (in general and also regarding oil spills) to the public and interested/affected parties?

5.5. Are you aware of how the national and $E U$ and global communication policies interact?

5.6. Do you know how regional risk communications relate to risk communication of those institutions having responsibility for risk assessment and/or risk management in regard of oil spills?

5.7. Does your organization work with changing public attitudes in regard of oil spills?

5.8. Does your organization work with lobbying in any sense in regard of oil spills?

5.9. Does your organization monitor other regulatory bodies in regard of oil spills?

6. Topic: Scientific uncertainties and information

6.1. From where do you receive the relevant information regarding the risk?

- Do you perform your own research or do you rely on other sources? 
- Do you rely on other source of knowledge (for example experiential/practical knowledge of stakeholders)?

6.2. Are you aware of any examples of scientific disagreement or uncertainty in the area of oil spills?

- If YES: How did you find out about it, and how can other be aware of this (e.g. in scientific publications, at scientific meetings, expert committees etc)?

- How do you cope with uncertainties and disagreements while dealing with the risk? (For example while performing risk assessment or identifying management options).

- Do you apply any management procedures for coping with disagreement and uncertainty? (i.e. external evaluations, hearings etc) 


\section{ANNEX 3: List of policy documents}

\section{BSAP. (2007). HELCOM Baltic Sea Action Plan.}

CDR (2009): The Committee of the Regions' White Paper on Multilevel Governance, Committee of the Regions $89 / 2009$.

\section{COMMISSION OF THE EUROPEAN COMMUNITIES} (2008). COMMUNICATION FROM THE COMMISSION TO THE COUNCIL AND THE EUROPEAN PARLIAMENT The role of the CFP in implementing an ecosystem approach to marine management. No. [SEC(2008) 449]. Brussels, 11.4.2008 $\operatorname{COM}(2008) 187$ final.

COMMISSION STAFF WORKING DOCUMENT accompanying the COMMUNICATION FROM THE COMMISSION TO THE EUROPEAN PARLIAMENT, THE COUNCIL, THE EUROPEAN ECONOMIC AND SOCIAL COMMITTEE AND THE COMMITTEE OF THE REGIONS concerning the European Union strategy for the Baltic Sea Region ACTION PLAN, (2009).

COP IV Decision IV/1. (1998). Unep/cbd/cop/4/27; report of the fourth meeting of the Conference of the Parties to the Convention on Biological Diversity. Bratislava, 4-15 May 1998. (Na.98-2674 061098).

COP V Decision V/6. (2000). Fifth Meeting of the Conference of the Parties to the Convention on Biological Diversity Nairobi, 15-26 May, Kenya, unpublished manuscript.

DIRECTIVE 2000/59/EC OF THE EUROPEAN PARLIAMENT AND OF THE COUNCIL of 27 November 2000 on port reception facilities for shipgenerated waste and cargo residues, (2000).

DIRECTIVE 2009/15/EC. DIRECTIVE 2009/15/EC OF THE EUROPEAN PARLIAMENT AND OF THE COUNCIL of 23 April 2009 on Common Rules and Standards for Ship Inspection and Survey Organisations and for the Relevant Activities of Maritime Administrations, (2009).

DIRECTIVE 2009/16/EC OF THE EUROPEAN PARLIAMENT AND OF THE COUNCIL of 23 April 2009 on Port State Control, (2009).

DIRECTIVE 2009/20/EC OF THE EUROPEAN PARLIAMENT AND OF THE COUNCIL of 23 April 2009 on the Insurance of Shipowners for Maritime Claims, (2009).

European Commission (2009): Commission Staff Working Document Accompanying the Communication from the Commission to the European Parliament, the Council, the European Economic and Social Committee and the Committee of the Regions Concerning the European Union Strategy for the Baltic Sea Region Action Plan.

European Commission (2012): Communication from the Commission to the European Parliament, the Council, the European Economic and Social Committee and the Committee of the Regions Concerning the European Union Strategy for the Baltic Sea Region, $\operatorname{COM}(2012)$ 128 final.

European Commission (2013a): Commission Staff Working Document Accompanying the Communication from the Commission to the European Parliament, the Council, the European Economic and Social Committee and the Committee of the Regions Concerning the European Union Strategy for the Baltic Sea Region, Action Plan, February 2013 Version, SEC(2009) 712-2.

European Commission (2013b): Commission Staff Working Document Accompanying the Report from the Commission to the European Parliament, the Council, the European Economic and Social Committee and the Committee of the Regions Concerning the Added Value of Macro-regional Strategies, SWD(2013) 233 final.

European Commission (2013c): Report from the Commission to the European Parliament, the Council, The European Economic and Social Committee and the Committee of the Regions Concerning the Added Value of Macro-regional Strategies, COM(2013) 468 final.

Havs- och vattenmyndigheten (Swedish Agency for Marine and Water Management). (2015). Förslag till inriktning för havsplaneringen med avgränsning av miljöbedömningen. (Ref. No 3779-14).

Havs- och vattenmyndigheten (Swedish Agency for Marine and Water Management). (2015). God Havsmiljö 2020. Marin strategi för Nordsjön och Östersjön. Del 4: Åtgärdsprogram för havsmiljön. Havs- och vattenmyndigheten report 2015:30. ISBN 978-91-8796704-7

HELCOM (1999): HELCOM Programme Implementation Task Force (HELCOM PITF), The Baltic Sea Joint Comprehensive Environmental Action Programme (JCP) Annual Report 1999.

HELCOM (2009a): Eutrophication in the Baltic Sea: An Integrated Thematic Assessment of the Effects of Nutrient Enrichment and Eutrophication in the Baltic Sea Region, Baltic Sea Environmental Proceedings no. 115B.

HELCOM (2009b): Biodiversity in the Baltic Sea: An Integrated Thematic Assessment on Biodiversity and 
Nature Conservation in the Baltic Sea, Baltic Sea Environment Proceedings no. 116B.

HELCOM (2010): Hazardous Substances in the Baltic Sea: An Integrated Thematic Assessment of Hazardous Substances in the Baltic Sea Region. No. 120B.

HELCOM (2012): Activities Report 2012. Baltic Sea Environment Proceedings no. 134.

HELCOM (2013a): THE BALTIC SEA JOINT COMPREHENSIVE ENVIRONMENTAL ACTION PROGRAMME (JCP) IMPLEMENTATION OF HOT SPOTS PROGRAMME, 1992-2013 final report.

HELCOM. (2013b). Joint HELCOM/OSPAR Guidelines on the Granting of Exemptions under the International Convention for the Control and Management of Ships' Ballast Water and Sediments, Regulation A-4.

HELCOM (2013c): Approaches and Methods for Eutrophication Target Setting in the Baltic Sea Region, Baltic Sea Environment Proceedings no. 133.

HELCOM. (2014). CONVENTION ON THE PROTECTION OF THE MARINE ENVIRONMENT OF THE BALTIC SEA AREA, 1992 (HELSINKI CONVENTION). Latest version with amendments.

HELCOM (2015): HELCOM annual report on discharges observed during aerial surveillance in the Baltic Sea

HELCOM GEAR (2013d): Roadmap of HELCOM Activities on Ecosystem Approach. Helsinki.
HELCOM GEAR (2014): Terms of Reference for HELCOM Group on the Implementation of the Ecosystem Approach (HELCOM GEAR) (As agreed by the HELCOM Heads of Delegation on 17 September 2014).

MSFD. DIRECTIVE 2008/56/EC OF THE EUROPEAN PARLIAMENT AND OF THE COUNCIL of 17 June 2008 Establishing a Framework for Community Action in the Field of Marine Environmental Policy (Marine Strategy Framework Directive), (2008).

MSPD. DIRECTIVE 2014/89/EU OF THE EUROPEAN PARLIAMENT AND OF THE COUNCIL of 23 July 2014 establishing a framework for maritime spatial planning, (2014)

Naturvårdsverket (Swedish Environmental Protection Agency). (2008). Ekosystemansatsen - en väg mot bevarande och hållbart nyttjande av naturresurser Naturvårdsverket.

POLISH MARITIME POLICY. (2015). Maritime Policy of the Republic of Poland up to 2020 (with perspectives up to 2030). Warsaw: Ministry of Infrastructure and Development; Department of Maritime Transport and Shipping Safety.

WFD. Directive 2000/60/EC of the European Parliament and of the Council of 23 October 2000 Establishing a Framework for Community Action in the Field of Water Policy (Water Framework Directive), (2000). 


\section{Bibliography}

Aps, R., \& Lassen, H. (2010). Recovery of depleted Baltic Sea fish stocks: A review. ICES Journal of Marine Science, (67), 1856-1860.

Bache, I. (2008). Europeanization and multilevel governance: Cohesion policy in the European Union and Britain. Rowman \& Littlefield Pub Inc.

Backer, H., Leppänen, J. M., Brusendorff, A. C., Forsius, K., Stankiewicz, M., Mehtonen, J., Vlasov, N. (2010). HELCOM Baltic Sea Action Plan - A regional programme of measures for the marine environment based on the ecosystem approach. Marine Pollution Bulletin, 60(5), 642-649.

Bäckstrand, K. (2006). Multi-stakeholder partnerships for sustainable development: Rethinking legitimacy, accountability and effectiveness. European Environment, 16(5), 290-306.

Bäckstrand, K., \& Lövbrand, E. (2015). Research handbook on climate governance. Edward Elgar Publishing.

Balsiger, J., \& VanDeveer, S. D. (2010). Regional governance and environmental problems. The International Studies Encyclopedia, 9, 6179-6200.

Balsiger, J., \& Debarbieux, B. (2011). Major challenges in regional environmental governance research and practice. Procedia Social and Behavioral Sciences, 14, 1-8.

Balsiger, J., \& VanDeveer, S. D. (2012). Navigating regional environmental governance. Global Environmental Politics, 12(3), 1-17.

Basedow, J., \& Wurmnest, W. (2006). Third-party liability of classification societies: A comparative perspective. Springer Science \& Business Media.

Bengtsson, R. (2009). An EU strategy for the Baltic Sea Region: Good intentions meet complex challenges. Swedish Institute for European Policy Studies, 9.

Berg, B. L. (1998). Qualitative research methods for the social sciences (3 ${ }^{\text {rd }}$ ed.). United States of America: Allyn \& Bacon.

Bernes, C. (2005). Förändringar under ytan: Sveriges havsmiljö granskad på djupet. Naturvårdsverket (Swedish Environmental Protection Agency).

Bonsdorff, E. (2006). Östersjön blir sig aldrig mera lik. In B. Johansson (Ed.), Östersjön - hot och hopp. Stockholm: Formas Fokuserar.

Boström, M., Grönholm, S., \& Hassler, B. (2016). The ecosystem approach to management in Baltic Sea governance: Towards increased reflexivity? In M. Gilek, M. Karlsson, S. Linke \& K. Smolarz (Eds.), Environmental governance of the Baltic Sea (pp. 149-172) Cham Heidelberg New York Dordrecht London: Springer Open.

Boyd, E. (2008). Navigating amazonia under uncertainty: Past, present and future environmental governance. Philosophical Transactions of the Royal Society B: Biological Sciences, 363(1498), 1911-1916. 
Brussard, P. F., Reed, J. M., \& Tracy, C. R. (1998). Ecosystem management: What is it really? Landscape and Urban Planning, 40(1), 9-20.

Bryman, A. (2002). Samhällsvetenskapliga metoder (1st ed.). Trelleborg: Liber Ekonomi.

Bulkeley, H., \& Newell, P. (2010). Governing climate change. Routledge.

Bunch, M., McCarthy, D., \& Waltner-Toews, D. (2008). A family of origin for an ecosystem approach to managing for sustainability. The Ecosystem Approach: Complexity, Uncertainty, and Managing for Sustainability. (pp 125-138). New York: Columbia Univ Pr.

Börzel, T. A, \& Panke, D. (2010). Europeanization. In M. Cini, \& N. Pérez-Solórzano Borrogán (Eds.), European Union Politics ( $3^{\text {rd }}$ ed) (pp 405-417). Oxford. Oxford University Press.

Cashore, B. (2002). Legitimacy and the privatization of environmental governance: How non-state market-driven (NSMD) governance systems gain rule-making authority. Governance, 15(4), 503-529.

Chasek, P. S., Downie, D. L., \& Brown, J. (2013). Global environmental politics. Westview Press.

Conca, K. (2012). The rise of the region in global environmental politics. Global Environmental Politics, 12(3), 127-133.

COP V Decision VI6. (2000). Fifth meeting of the Conference of the Parties to the Convention on Biological Diversity. Nairobi, Kenya 15 - 26 May 2000. Unpublished manuscript.

Creswell, J. W. (2014). Research design: Qualitative, quantitative, and mixed methods approaches $\left(4^{\text {th }} e d\right)$. Thousand Oaks, USA; London, UK; New Delhi, India; Singapore: Sage publications.

Curtin, R., \& Prellezo, R. (2010). Understanding marine ecosystem based management: A literature review. Marine Policy, 34(5), 821-830.

Debarbieux, B. (2012). How regional is regional environmental governance? Global Environmental Politics, 12(3), 119-126.

Endter-Wada, J., Blahna, D., Krannich, R., \& Brunson, M. (1998). A framework for understanding social science contributions to ecosystem management. Ecological Applications, 8(3), 891-904.

Engler, Cecilia. 2015. Beyond Rhetoric: Navigating the Conceptual Tangle Towards Effective Implementation of the Ecosystem Approach to Oceans Management. Environmental Reviews 23 (3): 288-320.

Esaiasson, P., Gilljam, M., Oscarsson, H., \& Wängnerud, L. (2003). Metodpraktikan: Konsten att studera individ, samhälle och marknad. Stockholm: Nordstedts Juridik AB,

COMMISSION STAFF WORKING DOCUMENT Accompanying the COMMUNICATION FROM THE COMMISSION TO THE EUROPEAN PARLIAMENT, THE COUNCIL, THE EUROPEAN ECONOMIC AND SOCIAL COMMITTEE AND THE COMMITTEE OF THE REGIONS concerning the European Union strategy for the Baltic Sea Region ACTION PLAN, (2009).

Evans, J.P. (2012). Environmental governance. Routledge New York. 
Fairbrass, J., \& Jordan, A. (2004). Multi-level governance and environmental policy. Multi-Level Governance, 147-164.

Fiorino, D. J. (1989). Technical and democratic values in risk analysis. Risk Analysis, 9(3), 293-299.

Gänzle, S., \& Kern, K. (2016). The European Union strategy for the Baltic Sea Region. In S. Gänzle, $\&$ K. Kern (Eds.), A 'macro-regional' Europe in the making: Theoretical approaches and empirical evidence (pp. 123-144). Hampshire and New York: Palgrave Macmillan.

Garcia, S. M. (2003). The ecosystem approach to fisheries: Issues, terminology, principles, institutional foundations, implementation and outlook. Food \& Agriculture Org.

Gilek, M., Hassler, B., Engkvist, F., \& Kern, K. (2013). The HELCOM Baltic Sea Action Plan: Challenges of implementing an innovative ecosystem approach. Political State of the Region Report 2013: Trends and Directions in the Baltic Sea Region. In Henningsen, B., Etzold, T., \& Pohl, A-L (Eds.). Baltic Development Forum.

Gilek, M., \& Karlsson, M. (2016). Seeking pathways towards improved environmental governance of the Baltic Sea. In M. Gilek, M. Karlsson, S. Linke \& K. Smolarz (Eds.), Environmental governance of the Baltic Sea (pp. 229-246) Cham Heidelberg New York Dordrecht London: Springer Open.

Gilek, M., Karlsson, M., Linke, S., \& Smolarz, K. (2016a). Environmental governance of the Baltic Sea: Identifying key challenges, research topics and analytical approaches. In M. Gilek, M. Karlsson, S. Linke \& K. Smolarz (Eds.), Environmental governance of the Baltic Sea (pp. 1-17). Cham Heidelberg New York Dordrecht London: Springer Open.

Gilek, M., Karlsson, M., Linke, S., \& Smolarz, K. (Eds.). (2016b). Environmental governance of the Baltic Sea. Cham Heidelberg New York Dordrecht London: Springer Open.

Glasbergen, P., \& Groenenberg, R. (2001). Environmental partnerships in sustainable energy. European Environment, 11(1), 1-13.

Gritsenko, D. (2013). The Russian dimension of Baltic maritime governance. Journal of Baltic Studies, 44(4), 425-449.

Gunningham, N. (2009). The new collaborative environmental governance: The localization of regulation. Journal of Law and Society, 36(1), 145-166.

Haahti, B., Hedenström, E., Linke, S., Lundberg, C., Reisner, G., \& Wanamo, M. (2010). Project environmental risk governance of the Baltic Sea: Case study report: Eutrophication. RISKGOV

Haas, P. M. (2000). Prospects for effective marine governance in the NW Pacific region. Marine Policy, 24(4), 341-348.

Haas, P. M. (2004). Addressing the global governance deficit. Global Environmental Politics, 4(4), 115.

Hammer, M. (2015). The ecosystem management approach: Implications for marine governance. In M. Gilek, \& K. Kern (Eds.), Governing Europe's marine environment. Europeanization of Regional Seas or Regionalization of EU policies? (pp. 75-92). Surrey, England: Ashgate. 
Hartje, V., Klaphake, A., \& Schliep, R. (2003). The international debate on the Ecosystem approach. Critical review international actors obstacles and challenges. Bundesamt fûr Naturschutz / Federal Agency for Nature Conservation.

Hassler, B. (2016a). Oil spills from shipping: A case study of the governance of accidental hazards and intentional pollution in the Baltic Sea. In M. Gilek, M. Karlsson, S. Linke \& K. Smolarz (Eds.), Environmental governance of the Baltic Sea (pp. 125-146) Cham Heidelberg New York Dordrecht London: Springer Open.

Hassler, B. (2016b). Transnational environmental collective action facing implementation constraints - the case of nutrient leakage in the Baltic Sea action plan. Journal of Environmental Policy \& Planning, 1-15.

Hassler, B., Boström, M., Grönholm, S., \& Kern, K. (2011). Environmental risk governance in the Baltic Sea - A comparison between five key areas: Deliverable number 8. RISKGOV.

Hassler, B., Söderström, S., \& Lepoša, N. (2010). Marine oil transportations in the Baltic Sea area: Deliverable number 6. RISKGOV.

Havs- och vattenmyndigheten. (2015a). Förslag till inriktning för havsplaneringen med avgränsning av miljöbedömningen. (No. Dnr 3779-14).

Havs- och vattenmyndigheten. (2015b). God havsmiljö 2020. Marin strategi för Nordsjön och Östersjön, del 4: Åtgärdsprogram för havsmiljön. (No. 2015:30).

Haward, M. G., \& Vince, J. (2008). Oceans governance in the twenty-first century: Managing the blue planet. Cheltenham, UK; Massachusetts, US. Edward Elgar Publishing.

Hegland, T. J., Raakjær, J., \& van Tatenhove, J. (2015). Implementing ecosystem-based marine management as a process of regionalisation: Some lessons from the Baltic Sea. Ocean \& Coastal Management, 117, 14-22.

HELCOM. (2010). Hazardous substances in the Baltic Sea - an integrated thematic assessment of hazardous substances in the Baltic Sea. (No. 120B).

HELCOM. (2013). THE BALTIC SEA JOINT COMPREHENSIVE ENVIRONMENTAL ACTION PROGRAMME (JCP). IMPLEMENTATION OF HOT SPOTS PROGRAMME, 1992-2013 final report.

HELCOM. (2015). HELCOM annual report on discharges observed during aerial surveillance in the Baltic Sea.

HELCOM GEAR. (2013). Roadmap of HELCOM activities on ecosystem approach.

HELCOM GEAR. (2014). TERMS OF REFERENCE FOR HELCOM GROUP ON THE IMPLEMENTATION OF THE ECOSYSTEM APPROACH (HELCOM GEAR) (As agreed by the HELCOM Heads of Delegation on 17 September 2014 Trans.).

Hjorth, R. (1994). Baltic Sea environmental cooperation. Cooperation and Conflict, 29(1), 11-31.

International Association of Classification Societies. (2011). CLASSIFICATION SOCIETIES - WHAT, WHY and HOW? IACS. 
Joas, M., Jahn, D., \& Kern, K. (2008). Governing a common sea: Environmental policies in the Baltic Sea Region. Routledge.

Johansson, B. (Ed.). (2006). Östersjön - hot och hopp. Forskningsrådet Formas.

Jouanneau, C. \& Raakjær, J. (2014). 'The Hare and the Tortoise': Lessons from the Baltic Sea and Mediterranean Sea Governance. Marine Policy, 50, 331-338.

Joyner, C. C. (2004). Rethinking international environmental regimes: What role for partnership coalitions. J.Int'L L \& Int'L Rel., 1, 89.

Julien, H. (2008). Content analysis. In L. M. Given (Ed.), The SAGE encyclopedia of qualitative research methods. Thousand Oaks: SAGE Publications Inc.

Karlsson, M., Gilek, M., \& Lundberg, C. (2016). Eutrophication and the ecosystem approach to management: A case study of Baltic Sea environmental governance. In M. Gilek, M. Karlsson, S. Linke \& K. Smolarz (Eds.), Environmental governance of the Baltic Sea (pp. 21-44) Springer.

Karlsson, M., \& Gilek, M. (2016). Governance of chemicals in the Baltic Sea Region: A study of three generations of hazardous substances. In M. Gilek, M. Karlsson, S. Linke \& K. Smolarz (Eds.), Environmental governance of the Baltic Sea (pp. 97-123) Springer.

Keough, H. L., \& Blahna, D. J. (2006). Achieving integrative, collaborative ecosystem management. Conservation Biology, 20(5), 1373-1382.

Kern, K. (2011). Governance for sustainable development in the Baltic Sea Region. Journal of Baltic Studies, 42(1), 21-35.

Knudsen, O. F., \& Hassler, B. (2011). IMO legislation and its implementation: Accident risk, vessel deficiencies and national administrative practices. Marine Policy, 35(2), 201-207.

Kooiman, J. (2008). Exploring the concept of governability. Journal of Comparative Policy Analysis: Research and Practice, 10(2), 171-190.

Lagoni, N. (2007). The liability of classification societies Springer Science \& Business Media.

Laizāne-Jurkāne, M. (2010). The Baltic Sea strategy: Illusions and perils. In Ž Ozolina, I. Reinholde \& T. Rostoks (Eds.), EU strategy for the Baltic Sea Region. A year after and beyond (pp. 233247) Zinātne.

Lamont, A. (2006). Policy characterization of ecosystem management. Environmental Monitoring and Assessment, 113(1-3), 5-18.

Lemke, P., Smolarz, K., Zgrundo, A., \& Wolowicz, M. (2010). Biodiversity with regard to alien species in the Baltic Sea Region. RISKGOV report to BONUS EEIG programme. ( No. 4). University of Gdansk, Institute of Oceanography, Gdynia:

Lemos, M. C., \& Agrawal, A. (2006). Environmental governance. Annual Review of Environment and Resources., 31, 297-325.

Lidskog, R., Soneryd, L., \& Uggla, Y. (2005). Knowledge, power and control—studying environmental regulation in late modernity. Journal of Environmental Policy and Planning, 7(2), $89-106$. 
Maltby, E. (2000). ECOSYSTEM APPROACH: FROM PRINCIPLE TO PRACTICE. Beijing. Ecosystem Service and Sustainable Watershed Management in North China. International Conference, Beijing, P.R. China, August 23 - 25, 2000

McLeod, K., \& Leslie, H. (Eds.). (2009). Ecosystem-based management for the oceans. Island Press. Washington D.C.: Covelo: London

Mee, L. D. (2005). Assessment and monitoring requirements for the adaptive management of Europe's regional seas. Managing European coasts. (pp. 227-237) Springer.

Meganck, R. A., \& Saunier, R. E. (2007). Dictionary and introduction to global environmental governance. Routledge.

Merlingen, M. (2011). From governance to governmentality in CSDP: Towards a Foucauldian research agenda. JCMS: Journal of Common Market Studies, 49(1), 149-169.

MSFD. DIRECTIVE 2008/56/EC OF THE EUROPEAN PARLIAMENT AND OF THE COUNCIL of 17 June 2008 establishing a framework for community action in the field of marine environmental policy (Marine Strategy Framework Directive), (2008).

Naturvårdsverket (Swedish Environmental Protection Agency). (2008). Ekosystemansatsen - en väg mot bevarande och hållbart nyttjande av naturresurser.

O'Mahony, J., \& Ottaway, J. (2009). Travelling concepts: EU governance in the social science literature. In B. Kohler-Koch, \& F. Larat (Eds.), European multi-level governance. Contrasting images in national research. Cheltenham UK. Northampton, MA, USA: Edward Elgar.

Oldberg, I. (2014). Rysslands roll i östersjörådet, barentsrådet och arktiska rådet. Nordisk Østforum, (01), 7-24.

Olsen, J. P. (2002). The many faces of Europeanization. JCMS: Journal of Common Market Studies, 40(5), 921-952.

Pavlikakis, G. E., \& Tsihrintzis, V. A. (2000). Ecosystem management: A review of a new concept and methodology. Water Resources Management, 14(4), 257-283.

Piattoni, S. (2010). The theory of multi-level governance: Conceptual, empirical, and normative challenges Oxford Univ Pr.

Pidgeon, N., Simmons, P., \& Henwood, K. (2006). Risk, environment, and technology. In P. TaylorGooby, \& J. Zinn (Eds.), Risk in social science (pp. 94-116) Oxford University Press.

Plummer, R., \& Fitzgibbon, J. (2004). Co-management of natural resources: A proposed framework. Environmental Management, 33(6), 876-885.

POLISH MARITIME POLICY. (2015). Maritime policy of the Republic of Poland up to 2020 (with perspectives up to 2030). Warsaw: Ministry of Infrastructure and Development; Department of Maritime Transport and Shipping Safety. 
Reinholde, I. (2010). How to govern the strategy? whether to govern at all ... ?. In Ž Ozolina, I. Reinholde \& T. Rostoks (Eds.), EU strategy for the Baltic Sea Region. A year after and beyond (pp. 41-58) Zinātne.

Renn, O. (2008). Risk governance: Coping with uncertainty in a complex world. London, UK; Sterling, USA: Earthscan/James \& James.

Rosenau, J. N. (2007). Governing the ungovernable: The challenge of a global disaggregation of authority. Regulation \& Governance, 1(1), 88-97.

Rostoks, T. (2010). In place of an introduction: Why the Baltic Sea strategy? In Ž Ozolina, I. Reinholde \& T. Rostoks (Eds.), EU strategy for the Baltic Sea Region. A year after and beyond (pp. 9-38) Zinātne.

Salines, M. (2010). Success factors of macro-regional cooperation: The example of the Baltic Sea Region. Bruges political research papers no. 12, March 2010.

Schymik, C., \& Krumrey, P. (2009). EU Strategy for the Baltic Sea Region - Core Europe in the Northern Periphery? Working Paper FG 1, 200908. SWP Berlin.

Selin, H., \& VanDeveer, S. D. (2015). European Union and environmental governance. Routledge.

Sellke, P., Dreyer, M., \& Linke, S. (2016). Fisheries: A case study of Baltic Sea environmental governance. In M. Gilek, M. Karlsson, S. Linke \& K. Smolarz (Eds.), Environmental governance of the Baltic Sea (pp. 45-71) Springer Open.

Sellke, P., Dreyer, M., \& Renn, O. (2010). Fisheries: A case study of environmental risk governance in the Baltic Sea. RISKGOV report to BONUS EEIG programme; dialogik gemeinnützige GmbH, Stuttgart, Germany. (No. 3).

Skjærseth, J. B., Stokke, O. S., \& Wettestad, J. (2006). Soft law, hard law, and effective implementation of international environmental norms. Global Environmental Politics, 6(3), 104120.

Smolarz, K., Biskup, P., \& Zgrundo, A. (2016). Biological invasions: A case study of Baltic Sea environmental governance. In M. Gilek, M. Karlsson, S. Linke \& K. Smolarz (Eds.), Environmental governance of the Baltic Sea (pp. 73-95) Springer Open.

Söderström, S., Kern, K., \& Hassler, B. (2015). Marine governance in the Baltic Sea: Current trends of Europeanization and regionalisation. In M. Gilek, \& K. Kern (Eds.), Governing Europe's marine environment. Europeanisation of Regional Seas or Regionalisation of EU policies? (pp. 163-181). Surrey, England: Ashgate.

Söderström, S., Kern, K., Boström, M., \& Gilek, M. (2016). 'Environmental governance’ and 'ecosystem management': Avenues for synergies between two approaches. Interdisciplinary Environmental Review, 17(1).

Soma, K., van Tatenhove, J., \& van Leeuwen, J. (2015). Marine governance in a European context: Regionalisation, integration and cooperation for ecosystem-based management. Ocean \& Coastal Management, 117, 4-13.

Stocchiero, A. (2010). Macro-regions of Europe: Old wine in a new bottle. Background Paper. Centre Studi Di Politica Internazionale Working Papers, 65, 2010. 
Szaro, R. C., Sexton, W. T., \& Malone, C. R. (1998). The emergence of ecosystem management as a tool for meeting people's needs and sustaining ecosystems. Landscape and Urban Planning, 40(1), 1-7.

Tamm Hallström, K., \& Boström, M. (2010). Transnational multi-stakeholder standardization: Organizing fragile non-state authority. Edward Elgar Publishing.

Tynkkynen, N. (2014). Russia and the Baltic Sea: Frames and spaces of environmental problems. Eurasian Geography and Economics, 55(6), 674-690.

Tynkkynen, N., Schönach, P., Pihlajamäki, M., \& Nechiporuk, D. (2014). The governance of the mitigation of the Baltic Sea eutrophication: Exploring the challenges of the formal governing system. Ambio, 43(1), 105-114.

Udovyk, O., Rabilloud, L., Gilek, M., \& Karlsson, M. (2010). Hazardous substances: A case study of environmental risk governance in the Baltic Sea Region. RISKGOV. Södertörns högskola.

Uggla, Y. (2007). Environmental protection and the freedom of the high seas: The Baltic Sea as a PSSA from a Swedish perspective. Marine Policy, 31(3), 251-257.

van Hoof, L. (2015). Fisheries management, the ecosystem approach, regionalisation and the elephants in the room. Marine Policy, 60, 20-26.

van Leeuwen, J., van Hoof, L., \& van Tatenhove, J. (2012). Institutional ambiguity in implementing the European Union Marine Strategy Framework Directive. Marine Policy, 36(3), 636-643.

van Leeuwen, J. (2010). Who greens the waves?: Changing authority in the environmental governance of shipping and offshore oil and gas production. Wageningen Academic Pub.

van Leeuwen, J., \& Kern, K. (2013). The external dimension of European Union marine governance: Institutional interplay between the EU and the international maritime organization. Global Environmental Politics, 13(1), 69-87.

van Tatenhove, J., Raakjaer, J., van Leeuwen, J., \& van Hoof, L. (2014). Regional cooperation for European seas: Governance models in support of the implementation of the MSFD. Marine Policy, 50, 364-372.

van Tatenhove, J., van Leeuwen, J., \& Soma, K. (2015). Marine governance as processes of regionalization: Conclusions from this special issue. Ocean \& Coastal management, 117, 70-74.

van Tatenhove, J. (2016). The environmental state at sea. Environmental Politics, 25(1), 160-179.

VanDeveer, S. D. (2014). Agenda setting at sea and in the air. In N. Kanie, S. Andresen \& P. M. Haas (Eds.), Improving global environmental governance: Best practices for architecture and agency (pp. 31-55). Abingdon and New York: Routledge.

Vangas, A. (2010). Can the EU strategy for the Baltic Sea Region bridge the 'Great divide'? In Ž. Ozolina, I. Reinholde \& T. Rostoks (Eds.), EU strategy for the Baltic Sea Region. A year after and beyond (pp. 103-119) Zinātne.

Vink, M. P., \& Graziano, P. (2007). Challenges of a new research agenda. In MP Vink and P. Graziano, (Eds.), Europeanisation: New Research Agendas. New York: Palgrave MacMillan, 320 . 
von Malmborg, F. (2003). Conditions for regional public-private partnerships for sustainable development — Swedish perspectives. European Environment, 13(3), 133-149.

Wang, H. (2004). Ecosystem management and its application to large marine ecosystems: Science, law, and politics. Ocean Development \& International Law, 35(1), 41-74.

Wenzel, B. (2011). Environmental governance and institutional interaction in the Baltic Sea Region: Effective governance system or institutional entanglement? (Master's Thesis).

WFD. Directive 2000/60/EC of the European Parliament and of the Council of 23 October 2000 establishing a framework for community action in the field of water policy (Water Framework Directive), EU Directive U.S.C. (2000).

Yin, R. K. (2014). Case study research: Design and methods ( $5^{\text {th }}$ ed.). California, USA; London, UK; New Delhi, India; Singapore: Sage Publications.

Young, O. R. (2008). The architecture of global environmental governance: Bringing science to bear on policy. Global Environmental Politics, 8(1), 14-32. 


\section{Papers}

The articles associated with this thesis have been removed for copyright reasons. For more details about these see:

http://urn.kb.se/resolve?urn=urn:nbn:se:liu:diva-133976 